\title{
POZNANIE A CNOSŤ V SÓKRATOVSKEJ LITERATÚRE
}

JAROSLAV CEPKO 


\section{Jaroslav Cepko \\ POZNANIE A CNOSŤ \\ V SÓKRATOVSKEJ LITERATÚRE}

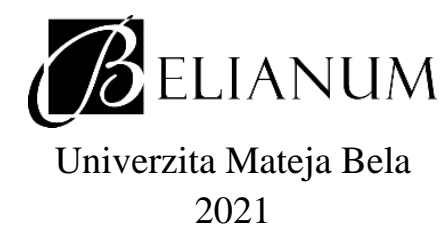


(C) Mgr. Jaroslav Cepko, PhD.

Publikácia vznikla ako súčast' grantového projektu VEGA 1/0094/20 Aristippos a sokratika.

Recenzenti: doc. Mgr. Andrej Kalaš, PhD.

doc. Mgr. Ulrich Wollner, PhD.

Vydavatel': Belianum. Vydavatel'stvo Univerzity Mateja Bela v Banskej Bystrici

Jazyková korektúra: Dana Wollnerová

ISBN $\quad 978-80-557-1922-1$

https://doi.org/10.24040/2021.9788055719221

\section{(c) $(i)$}

Táto publikácia je šírená pod licenciou Creative Commons Attribution-No-Derivates 4.0 International Licence CC BY-ND (uvedenie autora - bez odvodeného obsahu). 


\section{Obsah}

Úvod

1. Poznanie a cnost' 6

2. Sókratés 16

3. Sókratovská literatúra 29

4. Dve Obrany 41

5. Prípad Alkibiadés 51

Záver 61

Literatúra $\quad 63$ 


\section{Úvod}

Ciel'om tejto publikácie je sprevádzat' účastníkov „sókratovských seminárov" na Katedre filozofie Filozofickej fakulty Univerzity Mateja Bela v Banskej Bystrici. Jedným z nich je seminár „Poznanie a cnost' v sókratovskej literatúre" pre študentov magisterského stupňa, ktorý je súčast'ou modulu pod názvom „Poznanie a cnost' v antickej filozofii“. Viacero kapitol však možno využit' aj pre druhý, širšie koncipovaný seminár „Sókratés a jeho filozofický odkaz“.

Obsah spája systematický rozmer s rozmerom historickým. Problém prelínania epistemologickej a etickej roviny $\mathrm{v}$ antických textoch o Sókratovi je považovaný za východisko pochopenia povahy sókratovskej filozofie ako úsilia poznat' sám seba a stat' sa čo najlepším. Jednotlivé kapitoly si zároveň uchovávajú propedeutický charakter. Zámerom nie je ponúknut' vyčerpávajúcu analýzu skúmanej problematiky, ale poskytnút' študentom informácie o historickom, kultúrnom, náboženskom, filozofickom a literárnom kontexte, ktorý im pomôže lepšie situovat' čítané 
texty. Tomuto ciel'u sú podriadené prvé tri kapitoly: prvá osvetl'uje prehistóriu problematiky poznania a cnosti, druhá sa venuje postave Sókrata a spletitým problémom takzvanej „sókratovskej otázky“, tretia opúšt’a pôdu špekulácii o historickom Sókratovi a koncentruje sa na jeho literárne obrazy u sókratovských autorov. Už v druhej kapitole sa stretneme s Aristofanovou komédiou Oblaky, ktorá prezentuje istý pohl'ad na Sókrata, no nepatrí do žánru „sókratovských rozhovorov“. Štvrtá kapitola je úvodom k dvom literárnym pamiatkam týkajúcim sa súdneho procesu so Sókratom. Nejde v nich iba o negatívnu obhajobu pred žalobcami, ale najmä o pozitívnu obhajobu Sókratovho života a jeho chápania filozofie. Ťažiskom poslednej, piatej kapitoly je sókratovská výchova prezentovaná ako sebapoznanie a starost' o seba na príklade Sókratovho vychovávatel'ského vzt’ahu k Alkibiadovi, ako ho stvárňujú rovnomenné dialógy od viacerých sókratovských autorov. Aj v súvislosti s poslednými dvoma kapitolami, ktoré sa sústred'ujú na konkrétne texty, platí, že ponúkajú kontext a oporu pre analýzy a interpretácie, ktoré sa budú rozvíjat' počas stretnutí na seminári. Nenárokujú si byt' posledným slovom, ale pozvaním k ponoreniu sa do bohatstva jedného z prvých žánrov filozofickej literatúry.

Pokial' ide o prepis gréckych termínov, pre lepšiu čitatel'nost' ich uvádzame v prepise, ktorý rešpektuje pôvodné rozlíšenia typické pre grécku alfabetu $(t h=\theta ; t=\tau ; e=\varepsilon ; \dot{e}=\eta ; o=o ; o=\omega ; \dot{u}=o v)$. To isté platí aj pri transkripcii vlastných mien, s výnimkou citátov z prekladov, ktoré si stanovili iné transliteračné kritériá. V odkazoch na antickú literatúru názvy diel, pokial' je to možné, prekladáme do slovenčiny.

Pre lepšiu prehl'adnost' sme zvolili možnost' nerušit' plynulost' čítania kapitol poznámkami pod čiarou. Obsiahlejšie informácie, ktoré sú doplňujúceho charakteru a voči textu kapitoly druhoradé, nájde čitatel' vo vysvetlivkách zaradených na konci každej kapitoly. Tie obsahujú aj odkazy na antické pramene a d'alšie odborné a komentujúce publikácie, ktoré sú uvedené v záverečnom zozname literatúry.

Za cenné pripomienky pri finalizácii rukopisu d’akujem recenzentom a študentom. 


\section{Poznanie a cnost'}

Sme teda tej mienky, že cnost' je rozumovost', alebo ako celok, alebo nejaká čast? ${ }^{1}$

Témou tejto kapitoly bude slovné spojenie, ktoré figuruje nielen v názve kurzu, ale aj celého modulu: poznanie a cnost'. Aký je význam týchto dvoch pojmov a ako spolu súvisia? Ide o spojenie náhodné alebo sa za ním skrýva niečo, čo vypovedá o hlbšej podstate filozofie, najmä tej antickej, a zvlášst' sókratovskej?²

Na prvý pohlad ide o spojenie dvoch rovín, ktoré bežne vnímame oddelene: roviny epistemologickej, ktorá sa týka poznania, a roviny etickej, ktorá indikuje správne vedený život. Ak teda Platónov Sókratés v otázke, ktorá je mottom tejto kapitoly, hovorí, že cnost' je poznanie, máme tomu rozumiet' tak, že ich chce stotožnit? Znamená to - preložené do súčasného jazyka - že vedomosti nás robia dobrými, že kto vyniká po intelektuálnej stránke, vyniká ipso facto aj po stránke etickej? To znie pomerne kontroverzne, pretože bežná intuícia nám hovorí, že kto má vysoký inteligenčný kvocient, nijak ho to nemusí kvalifikovat' v mravnej oblasti. 
A naopak, človek pokladaný za nositel'a eticky pozitívnych vlastností ako je schopnost' pristupovat' $\mathrm{k}$ druhým férovo, odložit' bokom vlastné záujmy a nezištne pomáhat' druhým, a podobne - môže, ale nemusí mat' vyššie vzdelanie či široký intelektuálny rozhl'ad. Koniec koncov stačí poukázat' na to, ako l'udstvo dokázalo výdobytky vlastného poznania neraz cynicky zapriahnut' do aktivít, ktoré by sme sotva označili za eticky prípustné.

Rozlišovanie medzi etikou a epistemológiou (alebo „logikou“, pod ktorú sa vtedy zahŕňala) ako dvomi filozofickými disciplínami siaha $\mathrm{k}$ Aristotelovi a etablovalo sa v helenistickom období (v platónskej Akadémii pod vedením Xenokrata, ${ }^{3}$ ako aj v troch hlavných helenistických filozofických školách - u epikúrovcov, stoikov a skeptikov). To však neznamená, že predaristotelovská filozofia tieto dve roviny bezhlavo miešala, a ani to, že helenistické školy nevideli medzi týmito oblast'ami (a okrem nich aj filozofiou prírody, čiže ,fyzikou“) žiadne užšie prepojenia; skôr naopak. Práve hl'adanie prepojenia medzi etikou a poznaním, jeho obhajovanie či negovanie, nás núti zamysliet' sa, čo vôbec antickí myslitelia rozumeli pod poznaním a cnost'ou.

Môžeme azda predpokladat', že ušiam súčasného človeka druhý z týchto termínov znie už ako archaizmus a nesie na sebe nános konotácií spojených s krest'anskou morálkou a náboženstvom. Tento predsudok je ešte umocnený tým, že v ovzduší ,viktoriánskej“ meštianskej spoločnosti a jej mravov slovo „cnost“" nadobudlo značne oklieštený význam sexuálnej zdržanlivosti a prudérnosti. Odpomôct' od takéhoto chápania by nám mohol návrat ku gréckej etymológii tohto slova, kde areté (,cnost'“) súvisí s adjektívom aristos, ktoré znamená „najlepší“. Areté v takejto perspektíve potom znamená vlastnost', alebo súbor vlastností, ktoré človeka robia najlepším, akým sa môže stat'. Areté je tak rozvinutím toho, čo človeku pomáha vyniknút', realizovaním jeho najvnútornejšieho potenciálu. Jedným slovom, areté je „výbornost“"4 človeka, ono „dobro“, ktoré možno l'udskými prostriedkami dosiahnut'. Toto dobro stojí pred jednotlivcom ako pozvanie a úloha. Nie je človeku vopred dané, človek nemá areté „od prírody“ (fysei), ale na jej dosiahnutie musí vynaložit' úsilie, musí utvárat' 
sám seba, pestovat' sám seba. Dosahovanie areté je preto viazané na možnost' disponovat' sebou samým, a táto možnost' je v dobovom kultúrnom kontexte prístupná predovšetkým mužom, a to tým, ktorí sú slobodní (v protiklade k otrokom). ${ }^{5}$ Apel stat' sa ,„̌́o najlepším“ je preto v prvom rade adresovaný aristokratickej mládeži, u ktorej sa predpokladá nielen ,,politická" sloboda, ale aj sloboda od zaobstarávania živobytia, inými slovami dostatok vol'ného času (scholé). Prostriedkom a itinerárom takéhoto sebazdokonal'ovania je ,výchova“ (paideia). ${ }^{6}$

Ak hovoríme, že areté stojí pred človekom ako úloha, kladieme ju do vzt'ahu s tým, čo možno považovat' za ciel' života jednotlivca. Na tomto mieste nie je potrebné zachádzat' do spletitého problému zmyslu l'udskej existencie. Postačí, ak pripomenieme názor starých Grékov, že týmto ciel’om je „št'astie“ (eudaimonia). ${ }^{7}$ Zatial' čo v súčasnom jazyku výrok „št'astný život spočíva v cnosti““ znie ako apel na mravnú dokonalost', grécky výrok „eudaimonia spočíva v areté" vyznieva takmer tautologicky: „Dobrý život spočíva v dobrosti.“ V takejto perspektíve je otázka areté bezprostredne zviazaná s otázkou št'astného života, naplnenosti l'udskej existencie, čo je problém, ktorý akiste neprestal byt' aktuálny ani dnes.

„Ako sa stat' čo najlepším?“' Položit' si takúto otázku znamená mat' aspoň implicitné predporozumenie toho, čo človeka robí dobrým. Kto si trúfa hodnotit' druhých a sám seba, nazdáva sa, že „vie“, ktorá vlastnost' alebo súbor vlastností nesmie pri tomto hodnotení chýbat'. Tak sa v súvislosti s areté posúvame do kontextu poznania, prinajmenšom $\mathrm{v}$ podobe názoru na to, čo človeka robí hodnotným.

Azda najbezprostrednejším presvedčením, tak v minulosti, ako aj v súčasnosti, je stotožnenie hodnoty človeka s vnútorným prežívaním blaha. Inak a jednoduchšie, ,byt' dobrý“ v konečnom dôsledku znamená „mat' sa dobre“. V tomto svetle sa areté prejavuje ako „byt' zdravý“, „,byt' bohatý“", „byt' vážený a oceňovaný“. Odtial’ je len krôčik k tomu, aby takéto l’udové chápanie cnosti skízlo $\mathrm{k}$ hedonistickému pohl'adu na život: dobré je to, čo navodzuje príjemné pocity. Očividne ide o dobrá, ktoré zvyčajne nemáme úplne vo svojich rukách, ale vel'ký podiel na nich má aj 
nepredvídatel'ná náhoda. ${ }^{8}$ Preto $\mathrm{k}$ predstave výnimočného človeka, človeka s areté, patrilo aj to, že si tieto dobrá dokáže zaobstarat'. K areté teda patrí aj moc, a to nielen preto, že sama osebe chutí, že je príjemné mat' moc, ale najmä preto, že vd’aka nej si človek zabezpečí aj ostatné dobrá. Pregnantným vyjadrením takéhoto chápania areté sú slová mladíka Menóna v rovnomennom Platónovom dialógu: „Cnost' je [...] tešit’ sa z krásnych vecí a mat' na to moc. “9 Krásne, čiže dobré veci, o ktorých je reč, sú spomenuté o niečo nižšie: ,veci ako zdravie a bohatstvo [...], získanie zlata, striebra a pôct a úradov v štáte. “10

Toto prvotné mimoetické, alebo predetické chápanie areté ako schopnosti získavat' pre seba a mat' to, čo prispieva k pocitu dobrého života, je zasadené do širšieho rámca v celku aristokratickej výchovy, ktorá sa opiera o modelovanie života podla hrdinských vzorov. Namiesto abstraktných úvah a princípov sa predstava o správnom konaní vštepovala predovšetkým prostredníctvom príkladov, ktorými boli bud' historické postavy, alebo - a to v ešte významnejšej miere - postavy z básnickej tradície. Dôležité miesto tu zaujíma homérska epika (Ilias a Odysseia), ${ }^{11}$ no okrem nej aj rady pre dobrý život u lyrických básnikov ${ }^{12}$ a variácie na epické témy v attických tragédiách.

Zastavme sa na chvíl'u pri Homérovej Iliade. Tento epos, ktorý formoval mnohé generácie od archaickej doby až po sklonok antiky, bol ozajstnou encyklopédiou základných poznatkov a rezervoárom príkladov ako sa zachovat' v najrozmanitejších životných situáciách, a to najmä tých, ktoré by bolo možné označit' za kritické a hraničné. Platónovo označenie Homéra za ,vychovávatel'a celého Grécka“13 v tomto zmysle nie je prehnané. Celé stáročia si prostredníctvom počúvania a recitovania jednotlivých spevov helénsky svet osvojoval základné vzorce správania. Poslucháč Homéra pri svojich rozhodovaniach v sebe cítil apel zachovat' sa raz ako Achilles, inokedy ako Odysseus či iný z epických hrdinov. ${ }^{14}$

Ako je známe, dej eposu sa sústred’uje na pomerne krátky úsek obliehania Tróje achájskym vojskom. Vojna, ktorá trvala desat' rokov, vypukla vtedy, ked’ Paris, mladší syn trójskeho král'a Priama, zneužil pohostinnost' spartského krála Menelaa a potajme uniesol jeho manželku 
Helenu. Trestnú výpravu proti Tróji viedol Menelaov brat, argejský král' Agamemnón. V rámci tohto širokého kontextu básnik sústred’uje našu pozornost' na hnev Achilla, ktorého Agamemnón obral o najvzácnejšiu čast' vojnovej koristi - zajatkyn̆u Briseidu. Tento hnev hrdinu izoluje od spoločenstva Achájcov a vedomý si toho, že bez jeho pomoci šance na dobytie Tróje značne klesnú, Achillés sa z pomsty rozhodne z bitky stiahnut'. Vtedy ho zastihne d'alšie nešt'astie a d'alší motív k hnevu - smrt' jeho milovaného priatel'a Patrokla. Túto smrt' Achilles pomstí zabitím trójskeho hrdinu Hektóra, najstaršieho syna král'a Priama. K Achillovej vnútornej premene napokon prispeje to, že dokáže prejavit' súcit voči Priamovi, ktorý ho ponížený žiada o synovo telo. Vd'aka tomuto gestu Achilles napokon prekoná hnev a znova sa začlení do spoločenstva l'udí.

Mohli by sme povedat', že étos Iliady v určitom zmysle nadväzuje na vyššie opísaný základný étos zabezpečovania si dobrého života. Nosnou témou celej skladby je totiž otázka: „Kto je najlepší z Grékov?“ Charaktery postáv, a to nielen l'udských, ale aj božských, nie sú jednofarebné, nemožno o nich jednoznačne rozhodnút', či sú dobré alebo zlé. Sú naopak vel'mi plastické a básnikovi nemožno upriet' skutočnú vel'korysost' a nadstraníckost', pretože vel'kost' a nízkost', ušl'achtilost' a podlost' možno pozorovat' tak v tábore obliehatel'ov, ako aj v radoch obrancov obliehaného mesta. Kto je teda najlepší? Je to Achillés, zdatný v boji? Je to Agamemnón, vybavený všeobecne uznávanou autoritou? Alebo je to Odysseus, ktorý si vie poradit' v každej situácii?

V porovnaní s vyššie opísaným základným étosom, ktorý vidí hodnotu človeka v zdraví, bohatstve a moci, étos epických hrdinov naň na jednej strane nadväzuje, no na strane druhej ho aj prekračuje. Homérsky hrdina je súčast'ou stratifikovaného spoločenstva. Takmer bez výnimky je to anax - „muž stojaci na čele“, ,vodca“, „král”“. Jeho konanie a snaha presadit’ sa medzi ostatnými poprednými mužmi však nie je samoúčelná, nie je čisto sebecká. Je podriadená ciel'u, ktorým je dobyt' (respektíve ubránit') Tróju. Isteže, snaží sa aj získat' niečo pre seba, či je to vojnová korist' alebo zapísanie sa do pamäte budúcich generácí ,krásnou smrtou“. Práve tento chýr (kleos) o jeho činoch a hrdinskej smrti, ktorý zaznamená 
básnik (a Homér to naozaj aj robí), je hlavnou motiváciou hrdinu. Chce sa preto $\mathrm{v}$ prvom rade osvedčit' $\mathrm{v}$ boji, a to prostredníctvom telesnej sily a vytrvalosti (konštantný prívlastok, ktorý Homér dáva Achillovi, je „rýchlonohý"), ale aj osobnej odvahy a statočnosti, schopnosti zorientovat' sa v situácii (inými slovami praktickej rozumnosti), presadit’ svoj názor a múdro a presvedčivo prehovorit' pri porade vodcov, či sebaovládaním a umiernenost'ou podriadit' osobné ambície spoločnému ciel’u.

Jednotliví hrdinovia zosobňujú tieto vlastnosti v rôznom meradle. Všimnime si dvojicu, ktorá je po viacerých stránkach v nápadnom kontraste - Achillea a Odyssea. Obaja sú „králi“, obaja sú mužmi slov i činov, obaja sú vynikajúcimi bojovníkmi (hoci v tomto poslednom ohl'ade Odysseus za Achilleom zrejme zaostáva, no statočnost' Odysseovi nemožno upriet'). Rozdielni sú však svojím postojom k životu. Achilleov postoj by sme mohli označit' ako tragický - Achillés totiž do hĺbky precit'uje, že to, čo sa deje okolo neho, sa vymyká jeho moci. Je to dielo osudu, ktorý nemá v rukách. Vidno to na jeho „hneve“, ktorý nás básnik od prvého verša Iliady vyzýva pozorovat'. Tento hnev ovláda Achillea a hrdina sa ním necháva strhnút' a viest'. Prežíva aj momenty rezignácie, ked’ sa cíti „márne st'a bremeno zeme“" ${ }^{15}$ st'ahuje sa z diania a uvažuje o návrate domov. Do d'alšej aktivity ho znova vyburcuje nával hnevu a túžba pomstit' priatel'ovu smrt'. Osudovost' Achillovho príbehu sa odzrkadl'uje aj v momente jeho smrti: našla si ho zblúdená (či skôr božstvom, osudom riadená) strela, ktorá ho zasiahla do jediného zranitel'ného miesta - príslovečnej Achilleovej päty. ${ }^{16}$

Odysseus sa naproti tomu vyznačuje nápadným pragmatickým postojom k dianiu okolo seba. Homér ho opisuje ako človeka, ktorý si vie poradit' v množstve situácií (polymétis, polytropos). ${ }^{17} \mathrm{~V}$ Iliade je rešpektovaný medzi velitel'mi vojska, hoci vistom zmysle ho považujú za prefíkanca schopného dosiahnut' svoje ciele aj nie celkom čestnými prostriedkami. Táto jeho vlastnost' ho predurčuje pre misie, ktoré si okrem odvahy vyžadujú aj vel'kú mieru praktickej pohotovosti, rečníckeho talentu a ciel'avedomosti. Je to práve on, kto mal Achájcom poradit'stavbu dreveného koňa, ktorého Trójania vtiahli do mesta aj za cenu zborenia 
hradby, a sám sa ujal vedenia v ňom skrytej skupiny bojovníkov. ${ }^{18}$ Odysseus je ako hrdina praktickej múdrosti vykreslený aj v dohre trójskej vojny, ked' počas dlhého návratu domov musí čelit' nečakaným zvratom osudu, ku ktorým sa však vždy postaví aktívne, s jasným vedomím svojho ciel’a, ktorým je rodný ostrov Ithaka, jeho čakajúca manželka Pénelopé a syn Télemachos.

Básnická tradícia a s ňou spojená výchova bude d’alej rozvíjat' predovšetkým rozmer, ktorý by sme mohli označit ako achilleovský, to znamená zameranie na statočnost' v boji a vyrovnanie sa s osudom prostredníctvom trpezlivého nesenia jeho úderov. Najhlbším prejavom osudu je smrt', ktorú však možno prekonat' získaním slávy. Tragici vo svojich dielach poukazujú na t'aživú rozporuplnost' medzi l'udskými snahami a tým, čo sa v živote jednotlivcov deje bez toho, aby to mohli ovplyvnit'. Básnici komunikujú človeku poznanie o moci, ktorá stojí v pozadí nejednoznačnosti jeho existencie. Nezostáva mu nič iné, ako nad touto hrozivou skutočnost'ou žasnút' a akceptovat' ju.

Oproti tomuto poznaniu moci sa od 6. storočia pred Kristom rozvíja aj aktívnejší odysseovský prístup, ktorý vsadí na moc poznania. V oblastiach maloázijskej Iónie a na blízkych ostrovoch sa v tom čase začali rozvíjat' zárodky vied. Profiluje sa medicína, geografia, história, poznávanie prírodných javov. Gréci si začnú uvedomovat', že prostredníctvom systematického skúmania (historié) dokážu do určitej miery postavit' hrádzu proti onej nevyspytatel'nej moci náhody a osudu. L'udská znalost' v podobe techné (grécky termín, v ktorého význame sa spájajú naše pojmy umenia a remesla) predstavuje prostriedok oslobodenia človeka spod vplyvu neznámeho a neovplyvnitel'ného a zároveň možnost' stvárňovat' skutočnost' i samých seba podl'a vlastných predstáv. ${ }^{19}$

Dôležitost' poznania ako toho, čo dáva hodnotu l'udskému života a robí ho lepším, však nie je úplne bezproblémová. Ak je múdrost' onou najvyššou hodnotou, o ktorú sa má človek snažit', v čom táto múdrost' spočíva? Je možné dostat' sa k nej kumulovaním poznatkov zo všetkých možných oblastí? Nad takýmto chápaním varovne dvíha prst Efezan Hérakleitos: mnohoučenost' (polymathié) nie je totožná s rozumom 
(nús) ${ }^{20}$ Hromadenie informácií bez poňatia o tom, čo je skutočne dôležité, má d’aleko od múdrosti a je len stratou času. Čo je však týmto stredom, ku ktorému má konvergovat' budova l'udského poznania? Práve tu znovu vstupuje do hry otázka l'udskej dobrosti, a teda problém areté. Dôležité je to, čo sa týka nás, to, čo je „naše“. Poznatky o „cudzom“, o tom, čo je „mimo nás“, sú z tohto hladiska sekundárne, podriadené ciel’u, ktorým je dobrý a štastný život. Byt' múdrym bude teda spočívat' v „poznaní dobrého a zlého“, aby sme sa podla prvého utvárali a druhému sa vyhýbali.

Tak sa dostávame k zrodu filosofie ako „lásky k múdrosti“, k spojeniu poznania a etiky. Geograficky sa ocitáme v Aténach, časovo v druhej polovici 5. storočia pred Kristom. Zoznámme sa so Sókratom.

\footnotetext{
${ }^{1}$ Platón, Menón 89a.

${ }^{2}$ Prehl'ad antickej gréckej filozofie od Homéra až po helenizmus z hl'adiska otázky vzt'ahu poznania a cnosti ponúka Prior 1991. Sókratovi sa venuje na s. 43-90.

${ }^{3}$ O tom, že práve Xenokratés (395-313 pred Kr.), tretí scholarcha Akadémie, explicitne rozdelil filozofiu na tri oblasti - logiku, fyziku a etiku - sa dozvedáme od Sexta Empirika, Proti matematikom VII 16.

${ }^{4} \mathrm{~V}$ angličtine sa pre areté namiesto staršieho virtue udomácnil preklad excellence, čiže to, čo spôsobuje, že jednotlivec exceluje, vyniká medzi ostatnými. V slovensky písaných publikáciách prevláda tendencia prekladat' areté ako „Zdatnost'“, čo však môže asociovat' telesné kvality ako sila a fyzický výkon. V tejto publikácii budeme, napriek jeho nešikovnosti, používat' preklad „,cnost““ alebo - pokial' to bude možné - zostaneme pri gréckom znení areté (v ženskom rode).

${ }^{5} \mathrm{Ak}$ je areté to, čo robí človeka v čo najvyššej miere človekom, mohli by sme pojem areté interpretovat' aj ako l'udskú ,dôstojnost'“، Tu je však potrebné zdôraznit', že táto „dôstojnost'“ je pre Grékov výsledok sebautvárania jednotlivca, a tým je orientovaná smerom do budúcnosti a nepredstavuje univerzálnu kategóriu aplikovatel'nú na všetkých l'udí bez rozdielu. Takýto univerzalizmus v otázke l'udskej dôstojnosti sa objaví v náznakoch až v stoicizme a v plnej miere v krest’anskej vízii človeka ako bytosti stvorenej na boží obraz, a teda bytosti od momentu stvorenia dobrej, hoci od tejto pôvodnej dobrosti neskôr odpadne hriechom. Tým, že grécke náboženstvo nemá jasný koncept o pôvode človeka, jednotlivec u Grékov nie je bytostne dobrým ani zlým, ale dobrým sa môže „stat"“. Táto príležitost' sa v najväčšej miere ponúka slobodným mužom (či už ich sloboda vyplýva z toho, že pochádzajú z aristokratických kruhov, alebo sú občanmi demokratickej polis).
} 
To Grékom nebráni úvahám o tom, že existuje aj areté „žien, detí, starcov, otrokov“ (porovnaj Platón, Menón 71e-72a), tieto skupiny sa však môžu rozvíjat' iba vo svojich špecifických doménach (domácnost', manuálna práca a pod.) a ich potenciál nemá možnost' dosiahnut' a presiahnut' potenciál slobodného muža.

${ }^{6}$ Prehl'ad o rôznych formách inštitucionalizovanej výchovy v antickom Grécku ponúka monumentálna séria Jaeger 1946, 1947 a 1986. Nadväznost' medzi staršou, básnickou a aristokratickou výchovou a výchovou v sókratovskom kontexte skúma Zelinová 2018.

${ }^{7}$ Ďalší grécky termín, ktorý si vyžaduje určité spresnenie. V slovensky písanej literatúre sa zvykne prekladat' ako „blaženost“", čo môže so sebou niest' asociácie s krest'anským konceptom ciel'a l’udského života ako blaženej vízie Boha vo večnosti. Samotná krest’anská literatúra (novozákonná a patristická) však pre tento stav používa iný grécky termín, a to makariotés. Hoci v predkrest’anskej literatúre sa adjektíva eudaimón a makarios často používajú ako synonymá, je zrejmé aj to, že makariotés je chápané v silnejšom, definitívnom zmysle, ako možno doložit' pasážou z Aristotelovej Etiky Nikomachovej (I 1101a): „Blažený človek (eudaimón) sa nikdy nestane nešt'astným (athlios), pravda, nemôže ostat' ani št’astný (makarios), keby ho stihol Priamov osud. Ale nie je ani nestály, ani vrtkavý, lebo z pevného stavu blaženosti (eudaimonia) ho nič tak l'ahko nedostane, nijaké nešt’astia, ibaže by boli vel'ké a časté, z nich by sa pravdepodobne nestal zasa blaženým (eudaimón) vo vel'mi krátkom čase, a ak vôbec tak až po dlhých a naplnených rokoch, v ktorých by dosiahol vel'ké a krásne úspechy“ (preklad J. Špaňár). V novších anglických prekladoch, sa pre eudaimonia ustálil preklad happiness alebo happy life. Ked'že ide o pojem, ktorý viac zodpovedá Aristotelovej predstave o tom, že eudaimonia je síce vel'mi stabilný, nie však úplne definitívny stav dobrého života, ktorý zahŕňa tak dimenziu fyzickú, morálnu, politickú, a nevylučuje ani dimenziu religióznu, budeme v tejto publikácii (na rozdiel od vyššie citovaného Špaňárovho prekladu Aristotela) prekladat' eudaimonia výrazmi „št’astie“ alebo „št’astný život“", prípadne termín ponecháme v pôvodnom gréckom znení.

${ }^{8}$ Túto náhodnost' a slepú osudovost' Gréci nazývali tyché (v latinčine fortuna). Tá dokáže zo dňa na deň urobit' z chudobného boháča a z boháča chudobného, zo zdravého človeka chorého a - menej často - z chorého zdravého, z vplyvného a mocného človeka vyhnanca a naopak. Kult bohyne Tyché, Št’asteny (ale zároveň aj Nešt’asteny), bol zacielený práve na to, aby človek nadobudol pocit, že prostredníctvom modlitieb a obiet dokáže aspoň nejakým spôsobom ovplyvňovat' neovplyvnitel'né.

${ }^{9}$ Platón, Menón 77b.

10 Tamže $78 \mathrm{c}$.

${ }^{11}$ V slovenčine máme k dispozícii kvalitný preklad oboch Homérových eposov od M. Okála (Homéros 1986a, b).

${ }^{12}$ Už Hésiodos, po Homérovi druhý najvýznamnejší grécky básnik, vo svojich Prácach a dňoch formuluje v prvej osobe mravné súdy a poučenia, ktorých adresátom je jeho brat Persés. Kánon lyrických básnikov sa ustálil na deviatich autorov: Alkaios, Alkman, Anakreón, Bakchylidés, Ibykos, Pindaros, Sapfó, Simonidés a Stésichoros; to je však len úzky výber. Lyrika je typicky zasadená do kontextu hostín (sympósiî), ktorých funkciou 
bolo okrem iného vštepovat' aristokratickým mladíkom zásady potrebné pre život. O význame epiky a lyriky vo výchove porovnaj Porubjak 2010 a 2019.

${ }^{13}$ Ústava X 606e.

$14 \mathrm{Na}$ tento výchovný aspekt napodobňovania hrdinov a na význam orálnej kultúry pri osvojovaní si vzorcov správania upozornil E. Havelock (1963, 145-164).

15 Homér, Ilias XVIII 104.

16 Túto informáciu však nemáme z Homérovej Iliady, ale z iných prameňov. V Iliade zomierajúci Hektór predpovedá, že Achillés zomrie šípom, ktorý vystrelí jeho brat Paris, avšak príbeh o päte a o dôvode jej zranitel'nosti poznáme až z neskoršieho Statiovho eposu Achilleis (1. storočie po Kristovi).

${ }^{17}$ Homér, Ilias I 311; Odysseia I 1, X 330, XXI 274.

18 Opis v 2. speve Vergíliovej Aeneidy.

${ }^{19}$ Dejiny gréckej filozofie ako umenia dobrého života (techné tú biú) ponúka Suvák 2020. Kapitola o gréckom chápaní techné je na s. 43-54. Je zaujímavé, že v aténskom prostredí reflektujú význam l'udskej techné aj tragédie, ako možno vidiet' v óde na schopnosti človeka v Sofoklovej Antigone (v. 332-375).

${ }^{20}$ Porovnaj zlomok 22 B 40 [= Diogenés Laertský, Životy IX 1]. 


\section{Sókratés}

...človek, o ktorom by sme mohli povedat, že bol najlepši a vôbec najrozumnejši a najspravodlivejši zo všetkých súčasnikov, ktorých sme poznali. ${ }^{I}$

Sókratés ako prvý filozof? Tento titul môže na prvé počutie zniet' kontroverzne. ${ }^{2}$ Zvykneme predsa hovorit' o predsókratovských filozofoch na čele s Thalétom, ktorý žil dve storočia pred Sókratom. Na podporu tézy, že Sókratés je zakladajúcou postavou filozofie, však možno uviest' skutočnost', že termín filosofia a od neho odvodené slová sú v gréckej literatúre pred rokom 400 pred Kristom skôr vzácne. Narátali by sme nanajvýš zopár desiatok výskytov a všetky z nich možno situovat' do poslednej tretiny 5. storočia. Pred rokom 470 ich nikto nepoužíval. Od druhej dekády 4. storočia sa však s nimi takpovediac pretrhne vrece a ich výskyt možno rátat'v stovkách. ${ }^{3}$ Aká udalost' mohla spôsobit' takýto raketový nástup a rozšírenie slova, ktoré používame dodnes? Odpoved' je zrejmá: touto udalost'ou bol Aténčan Sókratés.

Atény sa v 5. storočí pred Kristom stali jedným z dvoch najsilnejších mocenských hráčov v gréckom svete (tým druhým bola Sparta). Na 
poli kultúry a vzdelanosti však nemali žiadnu konkurenciu. V období najväššieho rozkvetu, to znamená v klasickej ére, ked' na ich čele stál stratég Periklés, ${ }^{4}$ našla v Aténach svoj domov pomerne pestrá a diferencovaná intelektuálna scéna. Jednou z jej skupín boli skúmatelia prírody, ktorých v súčasnosti zvykneme označovat' ako „prírodných filozofov“. Ked’že predmet ich záujmu bola príroda (fysis), antika ich nazývala fyziológmi (fysiologoi). Zich radov svoju stopu v Aténach zanechal Anaxagoras, osobný priatel' Perikla a Euripida. ${ }^{5}$ Okrem neho v Aténach istý čas pôsobil „posledný z fyziológov“ Diogenés z Apollónie, ktorý svoj výklad sveta vyskladal z názorov predošlých myslitel’ov. Na oboch nadväzoval rodený Aténčan Archelaos. Ďalšiu dôležitú skupinu predstavovali učitelia múdrosti, ktorí prichádzali do Atén ponúkajúc vyššie vzdelanie pre mládež z bohatých rodín. Ujalo sa pre nich označenie „sofisti“, ktoré je odvodené od slova sofia, „múdrost'“. ${ }^{6}$ Záujem sofistov presahoval tradičné skúmanie prírody, našli sa medzi nimi polyhistori s encyklopedicky širokým rozhl'adom, ale aj učitelia rétoriky, ktorí dávali rady, ako sa presadit' pred politickým zhromaždením a ako vyhrat' súdne spory prostredníctvom premyslene zostavenej reči. Viacerí vd’aka svojim vzdelávacím aktivitám nadobudli značný majetok. ${ }^{7}$

Toto je prostredie, v ktorom sa objaví Sókratés, prostredie, ktoré ho formuje, vplýva naňho, inšpiruje ho, no zároveň sa od jeho zamerania čímsi líši. Zrejme aby tejto svojej odlišnosti dal nejaké meno, označuje svoje životné poslanie a svoj životný štýl novým výrazom - filosofein. Filozof nie je vlastník múdrosti, ale jej milovník - ten, kto ju hl’adá, pretože cíti, že má $\mathrm{k}$ nej ešte d'aleko. A toto hl'adanie nie je iba jednou fázou $\mathrm{v}$ živote, ale zaberá ho celý, je jeho hybnou silou. Inak povedané, filozofia je metóda ustavičného sebazdokonal'ovania, pretvárania seba, starostlivosti o seba. To Sókrata odlišuje od vyššie zmienených fyziológov, ktorí sa starajú o to, čo je mimo človeka. So sofistami má spoločný záujem o veci l'udské ${ }^{8}$ a o výchovu $k$ dobrému životu. Nesmieme sa preto čudovat', že bežní Aténčania považovali Sókrata za jedného z nich. Na rozdiel od sofistov, ktorí sa považujú za majstrov múdrosti, za ich pánov a vlastníkov, schopných odovzdávat' ju druhým, je však Sókratés presvedčený, 
že pravdu je treba vytrvalo hl'adat' a podrobit' sa jej. Nie človek si vytvára pravdu podl'a svojej miery, ale pravda transformuje človeka.

Čo o Sókratovi vieme? Je toho vel'a i málo zároveň. Mohli by sme dokonca povedat', že je toho málo práve preto, že je toho vel'a. Ide však o informácie z druhej ruky. Od samotného Sókrata sa nám nezachovalo nič v písomnej podobe, a to nie preto, že by sme nemali št'astie a jeho spisy by sa boli stratili - on jednoducho vôbec nepísal. Dnes by ho to ako filozofa diskvalifikovalo, no naše chápanie filozofie sa od Sókratovho značne líši - preňho totiž filozofovat' neznamenalo vytvárat' myšlienkový systém, ktorý by sa dal zachytit' v písomnej forme. Sókratovská filozofia bola snaha o pestovanie seba a druhých, jej metódou bol živý rozhovor a produktom vlastný život. Takéto chápanie filozofie a z neho vyplývajúci nezáujem o písomnú produkciu je dôvodom, prečo sme odkázaní na to, čo o Sókratovi napísali druhí.

Vyššie sme uviedli, že od začiatku 4. storočia pred Kristom sa v gréckej literatúre začína masívne objavovat' slovo filosofia a jemu podobné výrazy. Súvisí to s literárnou aktivitou Sókratových poslucháčov po jeho smrti. Vd’aka tomu disponujeme bohatým písomným materiálom o tom, čo Sókratés údajne hovoril, ako sa správal, čo považoval za dôležité. Bližšie sa s touto sókratovskou literatúrou zoznámime v tretej kapitole. Na tomto mieste nás zaujíma otázka, do akej miery sú tieto informácie hodnoverné. Inak povedané, aký je vzt’ah medzi „literárnym Sókratom“ a „historickým Sókratom“? Táto otázka, známa aj ako „sókratovský problém“9 sa s vel'kou razanciou vynorila v období osvietenstva a bola živená v radoch klasických filológov a historikov filozofie posledných dvoch storočí. Odzrkadl'ujú spisy sókratovských autorov to, aký bol Sókratés naozaj? Na jednej strane by sa dalo predpokladat', že áno. Dôvod je ten, že jednotliví autori by sa diskreditovali, keby vo svojich dielach prezentovali obraz o Sókratovi, ktorý by sa markantne odchyl'oval od spomienok, ktoré museli byt' medzi Aténčanmi ešte aj po desat'ročiach pomerne živé. Na druhej strane musíme konštatovat', že v jednotlivostiach sa obrazy Sókrata od seba dost' líšia. Stojí za tým skutočnost', že každý z autorov si zo Sókrata zapamätal a zdôraznil niečo iné. Vzhl'adom na to, 
že viacero Sókratových poslucháčov rozvíjalo filozofiu d’alej na vlastný spôsob, je celkom pochopitel'né, že niektoré učitel'ove tézy nechali vyniknút' v popredí, iné sa dostali do úzadia a všetky ich interpretovali po svojom. Navyše si musíme uvedomit, že úmyslom týchto autorov nebolo presvedčit' svojich čitatel'ov a poslucháčov, že onen Sókratés z mäsa a kostí pri takej alebo onakej príležitosti povedal tieto a tieto slová. Sókratovskí autori nie sú historikmi ani kronikármi, ba ani sa nesnažia tak prezentovat'. V paralele s výchovným rozmerom básnictva, o ktorom bola reč v prvej kapitole, by sme mohli povedat', že aj filozofia Sókrata a jeho žiakov si robí podobný, možno dokonca konkurenčný a alternatívny pedagogický nárok. V tomto zmysle sókratovskí autori chcú ponúknut' Sókrata ako istý druh hrdinu, oproti ktorému má čitatel' konfrontovat' svoj život. ${ }^{10}$ Literárny Sókratés tak plní funkciu modelu pre osobné sebautváranie. Jednotliví autori majú o tejto úlohe vo viacerých aspektoch podobnú predstavu, vonkoncom však nie identickú. Preto ich na jednej strane možno spoločne označit’ za sókratovcov, na strane druhej však medzi nimi možno sledovat' rozdiely, a to aj významné.

Pokial' ide o svedectvá o Sókratovi, zatial' sme sa zmienili o skupine jeho literárne činných žiakov. Ich obraz Sókrata bude teda nevyhnutne tendenčný - budú ho vykresl'ovat' v pozitívnom svetle, pretože je pre nich hrdinom filozofie. Najviac pozornosti sa v dejinách kritiky sústredilo na autorov, od ktorých máme k dispozícii celé diela, a to sú Platón a Xenofón. V d’alšej kapitole uvidíme, že sókratovských autorov bolo o niečo viac, no u zvyšných sme nemali tol'ko št'astia. V neskorších prameňoch sa nám zachovalo niekol'ko zlomkov zo spisov sókratovcov Aischina a Antisthena. O ostatných autoroch sa v tom lepšom prípade zachoval zoznam ich spisov, o ktorých obsahu môžeme len špekulovat'.

Okrem Platóna a Xenofónta sú pri pátraní po Sókratovi dôležité ešte dve svedectvá, ktoré nemožno považovat' za sókratovskú literatúru v tom zmysle, aký tomuto výrazu dáme nižšie, ale nanajvýš za literatúru o Sókratovi. Ide o Aristofanovu hru Oblaky a o niektoré pasáže, v ktorých sa o Sókratovi zmieňuje Aristotelés. Aristofanova komédia je ojedinelá a vzácna tým, že na rozdiel od ostatných svedectiev, bola napísaná ešte 
počas Sókratovho života. Do akej miery sa môžeme spoliehat' na jej historickú presnost' je vel'mi sporné. Ide totiž o komédiu a postava s menom Sókratés nesie silné znaky karikatúry. Aristofanovo zobrazenie Sókrata je teda tendenčné v inom zmysle ako jeho portréty z pera sókratovcov. Zámerom komédiografa je vyvolat' $v$ divákoch nevôl'u a pobúrenie, rozhodne teda nejde o objektívny a historicky presný prameň. U Aristotela, zdá sa, by sme mohli tendenčnost' vylúčit'. Nemožno ho upodozrievat', že by Sókrata chcel využit' ako nástroj šírenia svojich myšlienok, ani ho nechce zosmiešnit'. V tomto zmysle by sme azda mohli jeho svedectvo považovat' za najobjektívnejšie. Problém je však v tom, že ide o informácie neskoré a sprostredkované. Aristotelés sa narodil 15 rokov po Sókratovej smrti a do Atén sa dostáva až ako osemnást'ročný. To, čo vie o Sókratovi, sa dozvedel v prostredí Platónovej Akadémie. Niektoré jeho postrehy sú však aj napriek tomu zaujímavé. ${ }^{11}$

Aký je teda verdikt v otázke vzt’ahu ,historického“ a „literárneho“ Sókrata? Musíme byt' ostražití a vyvarovat' sa dvoch extrémov. Na jednej strane by nebolo rozumné nazdávat' sa, že Sókratés je čistá fikcia, výplod skupiny neskorších autorov. Je isté, že v Aténach v druhej polovici 5. storočia pôsobila osobnost' menom Sókratés, ba bola to osobnost' verejne známa, osobnost', ktorá vzbudzovala sympatie aj antipatie a jeho posolstvo by sa nestalo takou mimoriadnou inšpiráciou, keby išlo iba o povrchného diskutéra a moralizátora, akých mali Atény v tom čase nepochybne vel'a. Na druhej strane sa musíme vzdat' ilúzie o tom, že sókratovské rozhovory, ako ich dnes môžeme čítat' v zachovaných prameňoch, sú historickými záznamami. V skutočnosti sú zmesou autentických spomienok a fikcie. Táto zmes sa však ukázala a ukazuje ako nevyčerpatel'ný zdroj inšpirácie, a to nie napriek pluralite odlišných obrazov Sókrata, ale vd'aka nej.

Ak chceme skúmat' Sókratove postoje, opatrnost' nám radí hovorit' radšej o Platónovom Sókratovi, Xenofóntovom Sókratovi, Sókratovi z Oblakov a podobne. Dokonca by sme mohli zostúpit' ešte o úroveň nižšie a hovorit' o Sókratovi raných Platónových dialógov, Sókratovi 
z Menóna či o Sókratovi Ústavy, z ktorých ten posledný má k historickému Sókratovi akiste vel'mi d’aleko. V štvrtej kapitole sa bližšie pozrieme na rôzne obrazy Sókrata v Obranách od Platóna a Xenofónta. Napriek tomu existujú údaje, ktoré sa týkajú historického rámca Sókratovho života, a bolo by vhodné zrekapitulovat' ich na tomto mieste. Iste, mnohé z nich by sa dali spochybnit', ale pri biografických dátach ktorejkol'vek dávnej osobnosti si musíme v náležitých medziach dovolit' luxus spol'ahnutia sa na dostupné pramene.

Bezpečným životopisným údajom je jar roku 399 pred Kristom, kedy sa konal súdny proces a po krátkom väzení Sókratés zomrel následkom požitia jedu, čím bol vykonaný rozsudok smrti. Dožil sa sedemdesiat rokov, to znamená, že sa narodil v rokoch 470/469 pred Kristom. Bol aténsky občan z dému Alópeké. ${ }^{12}$ Meno Sókratés bolo v Aténach bežné (v Platónových dialógoch vystupuje aj jeho mladší menovec, u ktorého nie je dôvod predpokladat' príbuzenské väzby). ${ }^{13}$ Jeho otec Sófroniskos bol údajne remeselník, kamenár, hoci táto informácia nie je celkom istá. Matka sa volala Fainareté a mala byt' pôrodná babica (Platónov Sókrates často používa pre svoju vychovávatel'skú činnost' prirovnanie k práci pôrodnej babice). Fainareté sa po Sófroniskovej smrti znova vydala za Chairedéma, s ktorým mala syna Patrokla, Sókratovho o dvadsat' rokov mladšieho nevlastného brata. ${ }^{14}$ Sókratovou manželkou bola Xanthippé, ktorá sa stala príslovečnou pre údajnú hašterivú povahu. ${ }^{15}$ Neskorší životopisci hovoria o tom, že Sókratés mal okrem Xanthippy ešte jednu manželku menom Myrtó, dcéru alebo vnučku známeho aténskeho stratéga Aristeida prezývaného Spravodlivý. Diogenés Laertský zmieňuje viacero verzií o tomto dvojitom manželstve: bud' sa Sókratés najskôr oženil s Xanthippou a potom s Myrtó, alebo naopak; najviac bizarne znie tretia možnost', podl'a ktorej mal mat' obe súčasne podl'a zákona odhlasovaného s úmyslom zvýšit' v Aténach populáciu v čase vojen. Nie je celkom vylúčené, že Sókratés bol ženatý s Xanthippou a zároveň sa ujal ovdovenej a schudobnenej Myrtó bez toho, aby bola jeho manželkou. Najpravdepodobnejšie však je, že celý príbeh o dvoch ženách je len neskorším konštruktom opierajúcim sa o zmienku v Platónovom dialógu Faidón, že 
do väzenia prišli za ním ,ženy z jeho príbuzenstva“. ${ }^{16}$ Platón sa zmieňuje aj o troch Sókratových synoch. Ich mená sa dozvedáme z iných prameňov: Lamproklés, Sófroniskos a Menexenos. ${ }^{17}$

Zachovalo sa nám neobvykle vel'a narážok na Sókratov výzor: vypúlené oči; ploský, do hora vyhrnutý nos so širokými nozdrami; mäsité pery; arogantný, priam provokujúci výraz tváre. Jeho vlastní priatelia ho prirovnávajú k satyrovi, mýtickej figúre, ktorá po ikonografickej stránke pripomína čerta. Nosí ošumelý a nie celkom čistý odev, často chodí bosý. ${ }^{18}$

Pokial' ide o Sókratov spoločenský status, bol slobodným občanom z chudobnejšej strednej triedy. Zmienky o jeho chudobe sa konzistentne objavujú v prameňoch, vrátane Aristofana. Xenofón o ňom píše, že jeho majetok, vrátane domu, mal hodnotu pät' mín. ${ }^{19}$ Sókratés však chudobu nevnímal ako životnú okolnost', do ktorej bol dotlačený. Považuje ju skôr za súčast' svojho životného štýlu a osobnú výhodu. Chudoba mu pomáha plnit' jeho misiu. Inak by sme si nevedeli vysvetlit' napríklad jeho nedbalost' v odievaní a obúvaní. Sókratés jednoducho svojou chudobou demonštruje, že peniaze a to, ako sa človek javí navonok, nie sú preňho prvoradou hodnotou.

Sókratés bol aj aténskym vojakom. Občianstvo bolo totiž spojené s vojenskou službou. Slobodní Aténčania si mali podl'a svojich možností zabezpečit' výstroj a výzbroj a bojovat' za svoju polis. Tak sa aj Sókratés zúčastnil viacerých bitiek ako vojak t’ažkej pechoty (hoplités). ${ }^{20}$ Platón sa zmieňuje o troch vojenských akciách: bitke pri Poteidaii (432-429), Déliu (424) a Amfipole (422). Poteidaia, kolónia na jednom z úzkych „prstov“ polostrova Chalkidiké, sa vzbúrila a Aténčania mesto po dlhom obliehaní dobyli. Katastrofa ich však postihla cestou spät' pri Spartóle, kde utrpeli vel'ké straty a padli všetci traja stratégovia. Vtedy Sókratés zachránil raneného Alkibiada a jeho zbroj. ${ }^{21}$ Délion a Amfipolis boli miesta zdrvujúcich aténskych porážok, ktoré obec pripravili na akceptovanie podmienok takzvaného Nikiovho mieru v apríli 421. Sókratova vojenská kariéra skočila až v pomerne vysokom veku 47 rokov. Jeho udatnost' v Platónových dialógoch chvália Alkibiadés a Lachés. ${ }^{22}$ 
Okrem účasti vo vojenských t’aženiach Sókratés ukazuje svoju lojalitu mestu aj zastávaním politických funkcií. Treba mat' však na pamäti, že išlo o funkcie, ktoré boli pridel'ované losovaním, preto nemusíme u Sókrata predpokladat' ambíciu patrit' medzi tých, čo aktívne riadia osudy obce. V Platónovej Obrane sám o sebe tvrdí, že sa dožil vysokého veku iba vd'aka tomu, že sa v politike neangažoval. ${ }^{23}$ Došlo k tomu, že ako zástupca svojej fýly zastával úlohu prytana, a možno bol na jeden den̆ vylosovaný aj za predsedu zboru prytanov (epistatés). ${ }^{24}$ Platónov Sókratés kladie vel'ký dôraz na to, že v politike bol nestranný - dokázal sa postavit' na odpor tak svojvôli demokratov, ako aj oligarchov. ${ }^{25}$

Na základe týchto údajov by niekto mohol usúdit', že Sókratés viedol život poctivého občana, ktorý si plnil svoje vojenské i úradné povinnosti, a že jeho život s výnimkou niekol'kých dramatických momentov pri bojových akciách plynul pomerne nevýrazne, až nezaujímavo. Sókratés sa však z nejakého dôvodu stal aj postavou kontroverznou, čo napokon viedlo $\mathrm{k}$ jeho odsúdeniu a smrti.

V marci roku 423 bola na mestských dionýzovských slávnostiach uvedená Aristofanova komédia pod názvom Oblaky, v ktorej je Sókratés jednou z postáv. ${ }^{26}$ Aristofanés, v tom čase mladý, ambiciózny autor, bol po inscenácii sklamaný. Hra, ktorú on sám (a my spolu s ním) považoval za svoj majstrovský kúsok, skončila v sút'aži až na tret'om mieste, po Kratinovej komediálnej kritike pijanstva pod názvom Flaša a Ameipsiovej hre Konnos. ${ }^{27}$ Aristofanés o rok neskôr (422) protestuje proti neúspechu Oblakov v parabáze ${ }^{28}$ komédie Osy. Neskôr (po roku 420) Aristofanés Oblaky prepracoval a znova prihlásil do sút’aže, avšak nemáme doklad o tom, že by boli naozaj druhýkrát zinscenované. Druhá verzia (tá, ktorá sa nám zachovala) kolovala iba v podobe rukopisu. Platón, ktorý označuje Sókratovu karikatúru v Oblakoch za významný podnet k procesu so Sókratom, mohol poznat' iba túto druhú, nezinscenovanú verziu.

V komédii je hlavnou postavou Strepsiadés, Aténčan, ktorý sa bojí, že v súdnom spore príde o majetok. Preto posiela svojho syna Feidippida do školy, Sókratovej „Mysliarne“, aby sa naučil rečníckym trikom, ktoré 
by mu pomohli súd vyhrat'. Mladík sa však v škole naučí neúcte k rodičom a tradíciám, na čo sa Strepsiadés v hneve rozhodne „Mysliareň“ i s celým jej osadenstvom podpálit'. Už z tejto vel'mi stručnej synopsy je zrejmé, že autor komédie konfrontuje divákov so zmenami, ktoré do spoločnosti vnáša skupina intelektuálov podrývajúcich staré hodnoty a šíriacich novú morálku. Pre nás je zaujímavý obraz Sókrata: ten je prezentovaný ako vedúci školy, za sprostredkované vedomosti prijíma odmenu, čas trávi v koši zavesenom vo vzduchu pozorujúc oblaky, ktoré sú preňho novým božstvom, on sám i jeho žiaci žijú o hlade a v špine, ako ,živé mítvoly“، Moderní komentátori väčšinou konštatujú, že v postave Sókrata dochádza $\mathrm{k}$ fúzii rôznych typov aténskych intelektuálov, o ktorých sme hovorili na začiatku tejto kapitoly. Sókratés je skúmatel'om prírody, pretože podobne ako Diogenés z Apollónie a Archelaos považuje vzduch za hlavný metafyzický princíp. Okrem toho „robí silnejší dôvod slabším a slabší silnejším", čiže dokáže obratne a manipulatívne argumentovat' podobne ako sofistickí učitelia rečníctva a eristiky (argumentácie na dve strany, pri ktorej ciel'om je porazit' súpera, nie hl'adat' pravdu). So sofistami má spoločné aj to, že si za vyučovanie necháva zaplatit'. Nápadný je aj jeho ateizmus a relativizovanie hodnôt. Naproti tomu u sókratovských autorov Sókratés popiera, že by ho zaujímali veci na nebi a pod zemou, pri rozhovoroch zdôrazňuje, že mu ide o hl'adanie pravdy, svoju činnost' vykonáva bezodplatne a neraz dáva najavo svoju hlbokú úctu k božstvu. Je teda Aristofanov obraz Sókrata vonkoncom pokrivený? Je terčom jeho kritiky neexistujúca chiméra vyskladaná z charakteristík rôznych šíritel'ov novôt? Proti takejto interpretácii možno namietnut', že by to bolo netypické u komédiografa, ktorému pri vykreslení postáv zväčša išlo o to, aby ich diváci spoznali. V tejto súvislosti môže byt' zaujímavá aj hypotéza P. Vander Waerdta, ktorý sa nazdáva, že Aristofanés nám azda hovorí niečo, čo o Sókratovi a jeho intelektuálnej biografii nevieme, alebo pod vplyvom sókratovcov nechceme vediet'. Tento autor predpokladá, že iscenovanie Oblakov mohlo znamenat' prelom v Sókratovom živote. ${ }^{29}$ Sókratés pred Aristofanom mohol naozaj byt' skúmatel'om fysis, čomu by nasvedčovala aj zmienka u Platóna o jeho záujme o myšlienky fyziológov, najmä 
Anaxagora. ${ }^{30}$ Po Oblakoch tento svoj prístup mohol prehodnotit' a stal sa z neho ten, ktorý - parafrázujúc Ciceronove slová - stiahol filozofiu z neba na zem. Mladá generácia Sókratových poslucháčov mohla poznat' iba tohto postaristofanovského Sókrata a vehementne ho bránila. Ak je tento predpoklad správny, potom by Aristofanove Oblaky, napriek svojmu karikujúcemu, tendenčnému a pramálo filozofickému obsahu, boli skutočne zaujímavým dokumentom o Sókratovom myšlienkovom vývoji.

V roku 404 pred Kristom do Sókratovho života a do života celých Atén zasiahne ešte jedna udalost', ktorá prispeje $\mathrm{k}$ vzrastu antipatií voči nemu. Po porážke Atén v peloponézskej vojne spartský stratég Lysander dosadil v meste oligarchickú, prospartsky orientovanú vládu, ktorá sa stala známou ako vláda tridsiatich tyranov. Režim bol krátky (trval iba osem mesiacov), no zapísal sa do pamäte ako vel'mi násilný, skorumpovaný a krvavý. Vel’a demokratov utieklo z mesta a tí, čo v meste zostali (medzi nimi aj Sókratés) boli automaticky považovaní za sympatizantov, alebo aspoň tichých komplicov režimu. Nemáme dôvod mysliet' si, že by Sókratés osobne $\mathrm{k}$ oligarchickej krutovláde prispel alebo ju akokol'vek schval'oval. Aténčania si ho s ňou však spojili, pretože bolo známe, že viacerí jej exponenti - medzi nimi aj vodca tridsiatich, Kritias - patrili do Sókratovho krúžku. Okrem toho, že Sókratés rád trávil čas diskutujúc s Aténčanmi na agore, ${ }^{31}$ venoval sa aj stretnutiam s mladíkmi v remeselných dielňach $\mathrm{v}$ jej blízkosti či $\mathrm{v}$ gymnáziách na okraji mesta. Po reštaurácii demokracie si toto Sókratovo pôsobenie na zväčša aristokratickú mládež nové politické elity (medzi nimi aj Sókratov žalobca Anytos) interpretovali ako hrozbu a obvinili Sókrata z toho, že kazí mládež, neuznáva božstvá obce a zavádza nové božstvá. Tak napriek generálnej amnestii vyhlásenej hned' po návrate demokratov k moci na všetky zločiny oligarchického režimu, Sókratés v roku 399 stojí pred súdom a je odsúdený na smrt'. K okolnostiam a kontextu procesu sa vrátime v štvrtej kapitole. $\mathrm{V}$ poslednej, piatej kapitole bude príležitost' povedat' niečo viac aj o Sókratovej výchovnej aktivite. Proces so Sókratom a jeho smrt' boli však iskrou, ktorá naštartovala literárnu aktivitu jeho žiakov. A to je téma, na ktorú sa teraz sústredíme. 


\section{Sókratés}

${ }^{1}$ Platón, Faidón 118a.

2 Podl'a tradície zmienenej u Diogena Laertského (Životy I 12) mal ako prvý použit’ slová „filozof“ a „filozofia“" Pythagoras, aplikujúc ich na seba.

${ }^{3}$ Porovnaj Rossetti 2018, 268-269.

4 495-429 pred Kristom. Významný politik demokratických Atén, hoci sám pochádzal $\mathrm{z}$ aristokratického rodu. Viedol obec v začiatkoch peloponézskej vojny, podporoval umenie a kultúru. Jednou z okázalých stavieb, ktoré dal vybudovat', je aj známy Athénin chrám Parthenón na Akropole.

5 Anaxagoras (okolo 500-428 pred Kristom), pôvodom z maloázijských Klazomen, strávil v Aténach tri desat'ročia. Údajne bol v Aténach súdený za bezbožnost', preto sa uchýlil do mesta Lampsakos a tam aj zomrel.

${ }^{6}$ A to v dvojakom zmysle: bud' pozitívnom, ako prejav rešpektu a uznania (sofista ako „,múdry muž“), alebo v negatívnom (ten, kto múdrost' iba predstiera, „mudrák“, „mudrlant").

${ }^{7}$ Vymenovat' všetky významné postavy sofistického hnutia by si vyžiadalo vel'a priestoru. Najznámejšími zostávajú dvojica Prótagoras a Gorgias. Užitočný prehl'ad možno nájst' v Graeser 2000, 20-109; Guthrie 1971a; Rankin 2014, 13-146.

${ }^{8}$ Cicero o Sókratovi píše: „Sokrates prvý odviedol filozofiu od pozorovania neba, nechal ju zostúpit' do miest, ba zaviedol ju aj do domov a prinútil ju uvažovat' o živote a mravnosti, o dobre a zle“ (Tusculské rozhovory V 10, 12-14). Naráža tým na takzvaný ,antropologický obrat" od záujmu o prírodu k záujmu o človeku a spoločnost'. Sókratovi nemožno upriet' podiel na tomto obrate, no do vel'kej miery ho možno pripísat' už sofistom.

${ }^{9}$ K dejinám „sókratovského problému“ porovnaj Guthrie 1971b, 5-57; Porubjak 2012; Suvák 2017b, 11-42; Škvrnda 2020.

${ }^{10}$ Platón Sókrata štylizuje do role homérskeho hrdinu Achilla napríklad v Obrane 28b-d. Porovnaj Konrádová 2016; Wollner 2017.

${ }^{11} \mathrm{Na}$ základe toho, že Aristotelés niekedy používa meno Sókratés bez člena a inokedy s určitým členom (ho Sókratés), niektorí komentátori vyslovili predpoklad, že meno bez člena znamená historického Sókrata a meno s členom signalizuje, že reč je o literárnom Sókratovi z Platónových dialógov. „Sókratovský problém“ mal teda aj svoju antickú verziu. Medzi odborníkmi však nepanuje konsenzus ohl'adom toho, či je toto rozlíšenie úplne koherentné.

12 Démos bola územná jednotka, na aké sa delili Atény. Kleisthenés vo svojich demokratických reformách v roku 508 pred Kristom naviazal občianstvo na teritoriálnu príslušnost' $\mathrm{k}$ dému, aby oslabil aristokratické rodové väzby, pri ktorých bola dôležitá príslušnost' k „bratstvám“ (fratria).

${ }^{13}$ Vystupuje v dialógoch Theaitétos, Sofista a Štátnik; porovnaj aj Aristotelés, Metafyzika 1036b25. Doložených je 196 osôb s týmto menom v Aténach, z toho štyria sú starší ako náš Sókratés. Najstarší výskyt je zo 6. storočia pred Kristom (Nails 2002, 269). 
${ }^{14}$ Ak je možné stotožnit' tohto Sókratovho brata s Patroklom z Alópeky, ktorý bol okolo roku 406 pokladníkom Athéninho chrámu, a/alebo d’alším Patroklom (bez označenia dému), ktorý počas oligarchickej vlády Tridsiatich (v roku 404) zastával úrad archonta basileia, znamenalo by to, že bol vel'mi bohatým a vplyvným občanom. Stotožnenie týchto troch postáv však nie je isté (Nails 2002, 219).

${ }^{15}$ Platón ju vykresluje ako sympatickú postavu, ktorá súcíti s manželom v jeho posledný deň. Ako nel’ahkú povahu ju opisuje Xenofón. Ak je pravda, že v čase Sókratovej smrti jej najmladší syn bol batol'a a najstarší adolescent na prahu mužného veku (porovnaj Platón, Obrana 34d; Faidón 60a), znamenalo by to, že Xanthippé vtedy mohla byt' štyridsiatnička, teda takmer o tridsat' rokov mladšia od Sókrata. Do manželstva mohla vstúpit' vo veku 1520 rokov. Na základe jej mena niektorí usudzujú, že bola aristokratického pôvodu (Nails 2002, 299).

${ }^{16}$ Faidón 116b. Porovnaj Nails 2002, 209.

${ }^{17}$ Diogenés Laertský, Životy II 26. Dobovým zvykom bolo dávat’ prvorodeným synom meno po dedovi. Zaujímavé je, že Sófroniskos je až druhý v poradí.

${ }^{18}$ Porovnaj Platón, Theaitétos 143e; Hostina 215a-c, 216c-d, 220b, 221d-e; Xenofón, Hostina IV 19, V 5-7; Aristofanés, Oblaky 362.

${ }^{19}$ Xenofón, O hospodárení II 3. Dobový peňažný systém bol nasledovný: 6 obolov $=1$ drachma; 100 drachiem = 1 mína; 60 mín = 1 talent. $Z$ narážok v prameňoch usudzujeme, že 3 oboly (pol drachmy) boli považované za denné minimum pre robotníka. Chudobná rodina $v$ priemere minula za deň jednu drachmu. 5 mín by teda zodpovedalo rozpočtu chudobnej rodiny na približne jeden a pol roka. Platón v Obrane uvádza, že Sókratés navrhol sudcom, že zaplatí pokutu vo výške jednej míny (38b), pravdepodobne všetko, čo by mohol v tom čase dat'; naproti tomu sofista Euénos z Paru inkasuje za cyklus svojich prednášok celých pät' mín (20b).

${ }^{20}$ V Platónovom dialógu Kritón personifikované Zákony potvrdzujú, že Sókratés opúšt’al Atény iba vel’mi zriedka. Jednou z príležitostí boli práve vojenské výpravy: „[Býval si v obci] radšej ako všetci ostatní Aténčania [...]. Ty si nevyšiel nikdy z mesta ani na slávnost', iba raz na Istmos, ani nikam inam, iba niekam na vojenskú výpravu. Ani si nikdy nepodnikol nijakú inú cestu, ako to robia druhí l'udia“ (52b).

${ }^{21}$ Platón, Hostina 220d-e. Moment Sókratovho návratu z výpravy proti Poteidaii tvorí dramatické datovanie Platónovho dialógu Charmidés a spomína sa v jeho úvode.

${ }^{22}$ Porovnaj Platón, Hostina 220d-e; Lachés 191a-b.

${ }^{23}$ Platón, Obrana 31d. Mal mu v tom bránit' vnútorný hlas.

${ }^{24}$ Porovnaj Platón, Obrana 32b; Gorgias 473e; Xenofón, Helenika I 7, 15, Spomienky I 1, 8; IV 4, 2. Po Kleisthenovej reforme mala každá z desiatich aténskych fýl (,kmeňov“) pät'desiat zástupcov v rade (búlé). Rada teda mala spolu pät'sto členov, ktorí boli losovaní alebo volení. Exekutívnym orgánom rady bol zbor prytanov (prytaneis), to znamená 50 zástupcov jednej fýly, ktorých po funkčnom období trvajúcom desatinu roka vymenili zástupcovia d’alšej fýly. Formálne na čele zboru prytanov stál „predseda“ (epistatés). Ten sa 
menil každý deň; losovanie prebiehalo na úsvite. Viac o aténskej rade možno nájst' v Bleicken 2002, 226-242.

${ }^{25}$ Platón, Obrana 32a-e.

${ }^{26}$ Český preklad Aristofanés 1996. O Sókratovi v Oblakoch pozri Vander Waerdt 1994; Bromberg 2018; Capra 2018.

${ }^{27}$ Konnos bol podl’a Platóna Sókratov učitel' hudby (Euthydémos 272c; Menexenos 236a). Je preto celkom možné, že išlo o kritiku sofistický učitel’ov podobnú Aristofanovým $O b$ lakom. Nie je vylúčené, že Sókratés ako komická postava figuroval aj v Ameipsiovom Konnovi.

${ }^{28}$ Moment, kedy sa z javiska stiahnu herci a zbor prednáša spev určený publiku. Zvyčajne nesúvisí s dejom hry.

${ }^{29}$ O Sókratovom otrase po sledovaní Oblakov niečo naznačuje aj Xenofón (Spomienky I 1, 11-16).

${ }^{30}$ Platón, Faidón 96a-98b.

${ }^{31}$ Agora (tržnica) bola vel'ké centrálne aténske námestie, kde sa okrem obchodu konali aj masové stretnutia občanov. Agora a pril'ahlé stĺporadia predstavovali verejný priestor par excellence. 


\section{Sókratovská literatúra}

Sókratés sám nenapísal nič; vel'a sa však toho popísalo o ňom. ${ }^{1}$

Platón vo svojej verzii Sókratových rečí pred sudcami, kladie do úst obdivovaného majstra slová, ktoré znejú ako proroctvo. Ked' je už isté, že obvineného čaká smrt', povie tým, čo hlasovali za hrdelný trest: „Hovorím teda, občania, ktorí ste ma usmrtili, že po mojej smrti hned' príde na vás trest, ovel'a t'ažší, pri Diovi, než je smrt', na ktorú ste ma odsúdili; [...] Ešte viac bude tých, čo vás budú karhat' a ktorých som ja doteraz miernil, vy ste to však nespozorovali; a budú tým nebezpečnejší, čím sú mladší, a vás to bude tým viac mrziet'. “2 Nemusíme predpokladat', že na Sókratovi v tej chvíli spočinul prorocký duch. Stačí si uvedomit', že Platón, ktorý tieto slová napísal s časovým odstupom, už vedel, že Sókratov filozofický spôsob život mal svojich pokračovatel'ov aj po osudnom roku 399.

Koho - okrem Platóna samého - máme považovat' za týchto pokračovatel'ov? Ten istý Platón nám zanechal zoznam Sókratových blízkych priatel'ov, ktorí boli prítomní pri súde, ${ }^{3}$ a čiastočne odlišný zoznam tých, 
čo s ním strávili jeho posledný deň vo väzení. ${ }^{4} \mathrm{~K}$ nim ešte treba prirátat' d'alších, napríklad Aristippa z Kyrény, ktorý bol v tom čase na ostrove Aigina, či Xenofónta, vodcu gréckeho kontingentu bojujúceho v Malej Ázii na strane Kýra, ktorý si robil nárok na perzský trón proti svojmu bratovi Artaxerxovi II. ${ }^{5}$ Xenofón sa z Malej Ázie vrátil do Grécka až niekol'ko rokov po Sókratovej smrti.

Bezprostredne po majstrovej smrti sa jeho poslucháči - z celkom pochopitel'ného strachu z možného prenasledovania - na nejaký čas z Atén stiahli. Niektorí sa vrátili do svojich rodných obcí, kde okolo seba vytvorili skupiny nasledovníkov, zárodky neskôr sa profilujúcich filozofických škôl: Faidón v Élide na západe Peloponézu založil školu po istý čas zvanú élidská, ktorá sa však neskôr pod vedením Menedéma z Eretrie premenovala na eretrijskú. Eukleidés sa usadil v Megarách, ktoré boli susedom a rivalom Atén. Megarskú školu pre jej záujem o argumentáciu a logické paradoxy neskôr nazývali aj dialektickou. Do Megár k Eukleidovi sa po Sókratovej smrti mal stiahnut' aj Platón. Potom niekol'ko rokov cestoval a napokon sa vrátil do Atén, kde založil svoju školu. V Aténach $\mathrm{v}$ tom čase pôsobil aj Antisthenés, na ktorého praktický výklad Sókratovho učenia neskôr nadviaže Diogenés zo Sinópy a ním inšpirovaní kynici. ${ }^{6}$ Aristippos sa vrátil do svojej vlasti v líbyjskej Kyréne, a tam inšpiroval hedonistickú školu, ktorej stopy sa strácajú niekedy v polovici 3. storočia pred Kristom. Tieto štyri školy - élidsko-eretrijská, megarská, kynická a kyrénska - sa zvyknú označovat’ ako takzvané „malé sókratovské školy“.7

Antisthenovskou interpretáciou Sókrata bol po svojom návrate do Grécka zrejme inšpirovaný aj Xenofón, ten však nezhromaždil okolo seba nasledovníkov, ktorí by vytvorili školu. Vlastnú školu nezaložil ani Aténčan Aischinés, o ktorom z antických prameňov vieme, že dobre vychádzal z Aristippom.

Dozvuky Sókratovho prípadu v Aténach neutíchali ani v prvej dekáde 4. storočia. Rozruch vzbudil pamflet sofistu a rétora Polykrata pod názvom Obžaloba Sókrata. Tento spis napísaný ex post (okolo roku 390) 
sa nám, žial', nezachoval. ${ }^{8}$ Zdá sa však, že práve on vyprovokoval Sókratových poslucháčov, aby u verejnosti posilnili pozitívny obraz o svojom učitel'ovi. A tak Platón píše Obhajobu Sókrata, v ktorej Sókratés v prvej osobe obhajuje svoj život a vyvracia bod po bode body obžaloby. Zachovala sa nám Obhajoba aj od Xenofónta, ktorý ju rozširuje aj mimo kontext samotného procesu a ponúka tiež niekol'ko Sókratových myšlienok, s ktorými sa súkromne zveril niektorým svojim žiakom. Obom týmto krátkym dielkam sa budeme venovat' v štvrtej kapitole.

Nemôžeme s istotou povedat', či spomenuté obranné spisy boli prvé literárne prejavy sókratových žiakov. Vieme však, že reprezentujú nový žáner filozofickej prózy. Sókratovi nasledovníci odhadzujú nedôveru voči písanému slovu, ktorá bola vlastná ich majstrovi, no neponúkajú systematické traktáty, ani sa nevyjadrujú $\mathrm{v}$ hexametroch ako dávnejší predsókratovskí myslitelia, ani neskladajú monologické prejavy ako doboví sofisti a rétori. V písanej podobe sa snažia imitovat' kolokviálny charakter Sókratových živých rozhovorov, ktorých sami boli kedysi svedkami. Takto sa rodia „,sókratovské dialógy“ (Sókratikoi logoi) ${ }^{9}$ o ktorých neskôr referuje Aristotelés vo svojej Poetike (1447b11) ako o samostatnom a etablovanom žánri. ${ }^{10}$ Zmieňuje sa o nich v súvislosti s mímami Sófróna a Xenarcha, ${ }^{11}$ hoci tvrdí, že nie je možné zaradit' ich do jednej skupiny. Táto Aristotelova zmienka signalizuje, že komédie, ktoré čerpali námety z bežného života, opustili básnické metrum a začali používat' bežnú, hovorovú reč. Tak sa v prostredí, ktoré vd'aka znalosti písma a rozšírenej gramotnosti umožňovalo oddelit' literatúru od inscenovaných predstavení, vytvorili pre autorov podmienky, aby svoje diela koncipovali priamo pre čítajúcu verejnost'. Najvhodnejšou formou takéhoto prechodu z javiska k súkromnému čitatel'ovi bol dialóg. A ked’že filozofia, dištancujúca sa od rétoriky, sa podobne st'ahuje z verejného priestoru do priestorov súkromných, dialóg predstavuje zároveň ideálnu formu rodiaceho sa filozofického literárneho prejavu. ${ }^{12} \mathrm{~A}$ ak sme v predošlej kapitole - trochu kontroverzne - predstavili Sókrata ako prvého filozofa, je len prirodzené, že filozofiu, ktorú nepíšuci učitel' prevádzkoval v podobe živých 
rozhovorov, jeho žiaci zachytia v podobe mímu, v ktorom hlavnou postavou bude ich filozofický hrdina.

Tieto sókratovské dialógy možno považovat' za sókratovskú literatúru v užšom zmysle slova. Nejde totiž iba o literatúru, ktorá sa zmieňuje o Sókratovi (takou boli napríklad aj diela starej komédie, ako Aristofanove Oblaky alebo Ameipsiov Konnos), ale o zmes autentických spomienok na filozofické „súžitie“ (synúsia) s obdivovaným učitel’om a zároveň fiktívne rozvíjanie rôznych tém metódou spoločného skúmania odpozorovanou od neho. Ide teda o žáner, kde sa historická spomienka na Sókratove diskusie tvorivo reinterpretuje a každý autor svojho literárneho Sókrata používa na zdôraznenie vlastného chápania učitel'ovho dedičstva, na vyzdvihnutie parciálneho aspektu, ktorý ho zaujal, prípadne dokonca na šírenie vlastných myšlienok, ktoré boli výsledkom originálnej reflexie a už nemali s historickým Sókratom nič spoločné. Tento memoárový charakter sókratovských dialógov so sebou nesie ešte jednu dôležitú črtu, a to ich dočasnost'. Sókratovské dialógy vo vlastnom zmysle slova sú schopní napísat' iba tí, čo sa so Sókratom osobne stretli a mali s ním vlastnú skúsenost'. Preto ide o žáner jedinej generácie autorov, situovaný do prvej polovice 4. storočia. Dialóg prežije aj neskôr. Aj Aristotelés písal dialógy. Neboli to však sókratovské dialógy. Preto sa Aristotelés vyjadruje o Sókratikoi logoi ako o žánre uzavretom a porovnáva ho s inými žánrami minulosti.

Už sme sa zmienili o tom, že z nášho pohl'adu sú tými najdôležitejšími sókratovskými autormi Platón a Xenofón, a to z toho dôvodu, že iba od nich sa nám zachovali kompletné sókratovské dialógy. Vzhl'adom na prepracovanost' Platónových dialógov helenistickí autori zväčša predpokladali, že práve on bol „vynálezcom“ a zároveň vrcholným majstrom sókratovskej spisby v podobe dialógov. Toto je napríklad osobné presvedčenie neskoroantického životopisca Diogena Laertského. ${ }^{13}$ Ostatní sókratovskí autori by v takom prípade boli len neskoršími a viac či menej úspešnými napodobňovatel'mi tohto dokonalého vzoru. Niektorí moderní odborníci predpokladajú, že Platón sa myšlienkovo vyvíjal od pozície sókratovského autora k vlastnej, originálnej myšlienkovej koncepcii. Podl'a 
toho delia aj Platónove spisy na rané, sókratovské, v ktorých má Platónov literárny Sókratés najbližšie k historickému Sókratovi; stredné, v ktorých postavu Sókrata Platón využíva na vyjadrenie svojich filozofických postojov; a napokon neskoré, sebakritické, kde Platón reviduje názory svojho stredného obdobia ( $\mathrm{v}$ niektorých z týchto neskorých dialógov sa postava Sókrata dostáva na okraj, ba v posledných Zákonoch úplne mizne). ${ }^{14}$ Xenofóntov Sókratés (objavuje sa predovšetkým v jeho Spomienkach na Sókrata, Hostine, Obrane Sókrata a dialógu O hospodárení) je v porovnaní s Platónovým Sókratom považovaný za filozoficky menej sofistikovaného, dobrosrdečného sprostredkovatel'a praktických morálnych rád do života bez hlbšieho teoretického zázemia. Tento rozdiel niektorí odborníci považujú za dôvod, prečo by sa mala medzi Sókratom a Platónom robit' ostrejšia hranica: Sókratés zrejme nebol taký teoreticky podkutý diskutér, ako nám ho prezentuje Platón. Na druhej strane proti autenticite Xenofóntovho obrazu Sókrata možno namietat', že autor nebol očitým svedkom dôležitých posledných rokov Sókratovho života, pretože bol na výprave v Malej Ázii. K písaniu sa dostal zrejme až neskôr ako Platón a pri opise udalostí spojených s procesom so Sókratom a jeho smrt'ou sa musel spoliehat' na informácie z druhej ruky. Xenofóntov prakticky ladený Sókratés okrem toho prezrádza vplyv Antisthenovho vnímania učitel'ovho odkazu. ${ }^{15}$ V tomto zmysle Xenofón nie je typickým reprezentantom žánru Sókratikoi logoi. Je skôr jeho recipientom a tvorcom niečoho, čo by sa dalo označit' ako jeho ,re-make“. ${ }^{16}$

Okrem Platóna a Xenofónta antické pramene rátajú medzi sókratovských autorov d'alších štyroch, ktorých literárna pozostalost' sa zachovala iba v zlomkovitej podobe. Ich zoznam pod autoritou Panaitia zachoval Diogenés Laertský: „Panaitios myslí, že zo všetkých sokratovských dialógov sú pravé dialógy Platonove, Xenofontove, Antisthenove a Aischinove. Na pochybnostiach je ohl'adne dialógov Faidonových a Eukleidových, všetky ostatné však zavrhuje. “17 Okrem toho máme nie celkom jednoznačnú informáciu o tom, že sókratovské dialógy mal napísat' aj Aristippos. ${ }^{18}$ Moderná kritika sa venovala týmto osobnostiam a ich 
dielam spočiatku izolovane. Prelom nastal po publikovaní zbierky zlomkov sókratovských autorov od talianskeho filológa a historika filozofie G. Giannantoniho pod názvom Socratis et Socraticorum reliquiae (1990). Táto prebudila záujem o „menších“ sókratovcov, rekonštrukciu ich obrazov Sókrata a vzájomné porovnania. Vd’aka tomu vystúpili po tisícročiach z Platónovho tieňa a dnes už dokážeme o niečo lepšie uchopit' ich originalitu. Na báze Giannantoniho zbierky v posledných rokoch vychádza aj na Slovensku edícia prekladov a komentárov nazvaná Fontes Socraticorum. ${ }^{19}$ Pozostalost' dvoch dôležitých sókratovských autorov Antisthena a Aischina - je teda v podobe komentovaných zlomkov prístupná aj slovenskému čitatel'ovi.

Na margo počiatkov sókratovských dialógov stojí za zmienku pasáž z Diogena Laertského o obuvníkovi Simónovi. ${ }^{20}$ Sókratés údajne rád chodil do jeho dielne a „naživo“ tam viedol svoje rozhovory. Obuvník si vraj pri tom robil zápisky a životopisec uvádza zoznam tridsattri dialógov, ktoré dostali označenie „obuvnícke“. Simónova postava a jeho kontakty so Sókratom boli dlhú dobu považované za výplod legendy. V roku 1953 však archeológovia pri juhozápadnom rohu aténskej agory odkryli základy napohl’ad nevýznamného kamenného objektu z 5 . storočia pred Kristom. V ňom sa našli obuvnícke klince, kostené očká, ktoré mohli slúžit' na prevliekanie šnúrok, a najmä zvyšky nádoby s nápisom Simónos („patriace Simónovi“). Ak tento nález potvrdzuje existenciu Sókratovho súčasníka obuvníka Simóna, ešte to neznamená, že tento Simón bol prvým sókratovským autorom. Naše dva najdôležitejšie zdroje - Platón a Xenofón - o ňom mlčia. ${ }^{21}$ „Obuvnícke dialógy“ sa pripisujú aj Faidónovi alebo Aischinovi. ${ }^{22} \mathrm{Na}$ druhej strane, v zozname Faidónových diel sa objavuje dialóg pod názvom Simón. ${ }^{23}$ Absencia systematiky v zozname Simónových údajných dialógov by mohla naznačovat', že zoznam nebol umelo skonštruovaný. Ak je však pravda - ako nás informuje životopisec - že všetkých tridsat'tri dialógov sa zmestilo na jediný zvitok, potom by priemerná dížka každého dialógu bola iba jedna-dve tlačené strany. Simónova osobnost' a najmä jeho údajná spisovatel'ská aktivita teda nad'alej vyvolávajú množstvo otáznikov. Pravdepodobnejším stále zostáva predpoklad, 
že sókratovská literatúra mala svoj počiatok až po Sókratovej smrti, a to ako apologetická reakcia na štylizovanú Anytovu obžalobnú reč napísanú Polykratom. $^{24}$

Vrát'me sa preto $\mathrm{k}$ autorom, ktorých sókratovské spisy sú lepšie doložené v prameňoch. Podl'a všetkého vekovo najstarším bol Antisthenés. ${ }^{25}$ Pochádzal z Atén, ale ked’že jeho matka bola cudzinka (z Thrákie), Antisthenés nebol občanom. ${ }^{26}$ Spočiatku ho malo prit’ahovat' učenie sofistov, ba sám vytvoril okolo seba okruh poslucháčov. Ked' sa neskôr stretol so Sókratom, prešiel k nemu aj so svojimi žiakmi a mal povest' najvernejšieho Sókratovho nasledovníka. Diogenés Laertský nám zachoval impozantný zoznam Antisthenových spisov, čo naznačuje, že vo svojej dobe bol naozaj plodným spisovatel'om, ktorý kvantitou spisov pravdepodobne prevýšil aj Platóna. Niektoré z jeho diel sú nazvané podl'a postavy, iné majú tematický názov (niekedy ide o kombináciu obidvoch). Z toho možno usúdit', že prvé mali formu dialógu, druhé mohli byt' systematickejšími pojednaniami. Nápadný je počet názvov odvíjajúcich sa od mytologických postáv a motívov. Anitsthenés sa teda vo vel'kej miere zaoberal výkladmi Homéra, ale jeho alegorická interpretácia na rozdiel od sofistickej fyzikálnej racionalizácie mala skôr morálnu povahu. Zachovali sa nám aj jeho dva súvislé texty na motív sporu o Achillove zbrane medzi hrdinami Aiantom a Odysseom. Ide o dve ukážkové reči, v ktorých sa autor odklán̆a od homérskeho étosu fyzicky silného, no nie práve najbystrejšieho bojovníka (stelesňovaného Aiantom) k prototypu nového, sókratovského hrdinu, vyznačujúceho sa rozumnost’ou (znázorneného v Odysseovi). ${ }^{27}$ Okrem rozumnosti Antisthenés v zachovaných zlomkoch kladie dôraz na praktické rozvinutie Sókratovho odkazu. Rozumnost' vedúca k cnosti nie je podl'a neho výsledkom teoretizovania a množstva rečí, ale vyžaduje si „sókratovskú silu“, to znamená prvok osobného odhodlania, ktoré sa upevňuje cvičením. V tomto kontexte treba chápat' heslo „námaha je dobro“. Cnost' a blažený život nie sú výsledkom intelektuálneho osvietenia, ale životnej praxe. V tomto sa Antisthenova interpretácia Sókratovho posolstva stáva myšlienkovým podhubím kynizmu u Diogena, Kratéta a d'alších predstavitel'ov tohto významného hnutia. ${ }^{28}$ 
Nesmieme sa preto čudovat', že antickí životopisci a doxografi považovali Antisthena za zakladatel'a kynickej školy, hoci historicky je táto informácia sporná.

K užšiemu kruhu Sókratových poslucháčov patril aj Aischinés $\mathrm{z}$ aténskeho dému Sféttos. ${ }^{29}$ Pramene sú ohl'adom jeho života pomerne skromné. ${ }^{30}$ Hoci bol oddaným Sókratovým poslucháčom, zdá sa, že Aischinés po mravnej stránke príliš nevynikal. Sám bol chudobný, no vel'mi túžil po majetku, ktorý sa mu ale nedarilo získat'. Požičiaval si peniaze, ktoré nevracal, utápal sa v dlhoch, zaplietal sa do majetkových súdnych sporov. Vidina lepšieho zabezpečenia ho údajne priviedli na dvor syrakúzskeho tyrana Dionýsia, kde v tom čase pôsobili aj d’alší dvaja sókratovci - Platón a Aristippos. Aischinés k sebe nepritiahol žiadnych žiakov, ani sa sám nepridal k žiadnej sókratovskej ,škole“. Osobne si najlepšie rozumel s Aristippom. Napriek tomuto nevýraznému životu bol Aischinés v antike považovaný za výborného spisovatel'a a štylistu. Diogenés Laertský mu pripisuje sedem dialógov, o ktorých výslovne hovorí, že boli sókratovské. ${ }^{31}$ Údajná Aischinova vernost' v literárnom zobrazení Sókrata a jeho rozhovorov mu na jednej strane vyslúžila vyššie zmienenú chválu, na druhej strane vyvolala pochybnosti o tom, či bol Aischinés ich skutočným autorom: Aristippos sa o ňom po prečítaní jeho spisov vyjadril, že je zlodej, ${ }^{32}$ iní si zas mysleli, že Aischinés dostal od Sókratovej manželky Xanthippy prepis autentických Sókratových diskusií a on ich potom vydával za svoje dielo. ${ }^{33} \mathrm{~V}$ Aischinovom prípade máme tak trochu št’astie v nešt’astí: hoci sa nám nezachoval žiaden kompletný spis, disponujeme pomerne rozsiahlymi zlomkami z jeho dialógov Alkibiadés a Aspasia. ${ }^{34}$ Spoločnou témou obidvoch spisov je Sókratov spôsob výchovy. ${ }^{35}$ K Aischinovmu Alkibiadovi sa ešte podrobnejšie vrátime v poslednej kapitole.

Dvojica autorov, o ktorých sa vyššie citovaný Poseidónios vyjadril ako o sókratovských autoroch iba s rezervou sú Faidón a Eukleidés. Obidvaja boli v Aténach cudzincami a po Sókratovej smrti sa vrátil do svojich rodných obcí - Élidy a Megár - a založili tam svoje ,školy“. Stručný Faidónov životopis pôsobí až príliš melodramaticky na to, aby mohol byt' 
vierohodný: Pochádzal vraj z aristokratickej rodiny, ako vojnový zajatec upadol do otroctva a do Atén prichádza ako sexuálny otrok. Stáva sa Sókratovým poslucháčom a niekto z bohatých Sókratových priatel'ov ho vykúpi z otroctva. ${ }^{36}$ Známym sa stal predovšetkým ako rozprávač Platónovho dialógu posledného Sókratovho dňa vo väzení a na tejto zemi. Diogenés Laertský uvádza viacero spisov, kolujúcich pod Faidónovým menom, no za autentické považuje iba dva dialógy - Simón a Zópyros. Ani jeden sa nám nezachoval. O obuvníkovi Simónovi sme sa už zmienili v súvislosti s legendárnymi počiatkami sókratovskej literatúry. Protagonista druhého dialógu je perzský mág Zópyros, znalec v odbore fysiognómoniky, umenia z fyzických čŕt človeka odhadnút' jeho vnútorný charakter. ${ }^{37}$ Zópyros sa stretáva so Sókratom a podl’a rysov jeho tváre ho vyhlási za hlúpeho a zmyselného človeka. Ked' Sókratovi spoločníci poukážu na to, že vôbec nehovorí pravdu, a začnú sa mágovmu umeniu posmievat', Sókratés na počudovanie všetkých povie, že od prírody je naozaj taký, akého ho opísal tento cudzinec. Svoje prirodzené inklinácie sa mu však podarilo premôct' vd'aka rozvíjaniu rozumových schopností. Dialóg potom pokračuje diskusiou o možnostiach, ako výchovou naprávat' nedostatky prirodzenosti. ${ }^{38}$ Najmenej št'astia máme v prípade Eukleida. ${ }^{39}$ Poznáme iba názvy šiestich jemu pripísaných dialógov, o ktorých sa môžeme iba na základe názvu dohadovat', že aspoň niektoré boli sókratovskej povahy: Lamprios, Aischinés, Foinix, Kritón, Alkibiadés, O láske. ${ }^{40}$ Zvyšok životopisu u Diogena Laertského je venovaný Eukleidovým logickým skúmaniam a menoslovu žiakov.

Po tomto stručnom prehl'ade o pôvode a predstavitel'och sókratovskej literatúry sa bližšie pozrieme na jej zakladajúci moment, totiž súd so Sókratom. V Platónovej Obrane uvidíme, ako tento najznámejší Sókratov poslucháč interpretuje a obhajuje jeho život, čo považuje za jeho životné poslanie a ako sa v tomto obraze spájajú témy poznania, cnosti a výchovy. Platónov opis porovnáme so stručnejším a svojou povahou dost' odlišným podaním od Xenofónta. Napokon sa pozrieme ako sa témy výchovy, sebapoznania a sebazdokonal'ovania ukazujú v troch dialógoch, v ktorých spolu vedú rozhovor Sókratés a Alkibiadés. 
${ }^{1}$ Montuori 1998, 11.

2 Platón, Obrana 39c-d.

3 Tamže 33d-e.

4 Faidón 59b-c.

${ }^{5}$ Maloázijskú výpravu Xenofón neskôr opísal v známej Anabáze.

6 To, že kynické hnutie bol považované za pokračovatel'a sokratiky, možno doložit' aj anekdotickou informáciou zo života Zénóna, zakladatel'a stoicizmu: Ked' sa dostal do Atén a hl'adal človeka, ktorý by sa podobal Sókratovi, istý kníhkupec ho poslal za kynikom Kratétom (Diogenés Laertský, Životy VII 3). Porov. Flachbartová 2015, 95-160.

7 Toto označenie pochádza od nemeckého klasického filológa a historika filozofie z 19. storočia Eduarda Zellera (1843, 104-133). „Malé“ školy Zeller chápal ako menej významný doplnok k onej (z nášho pohl'adu) „,vel'kej“ škole, ktorou bola Platónova Akadémia. Platón podla Zellera pochopil Sókrata v jeho plnosti, kým ostatní jeho žiaci boli iba jeho „nedokonalými“" nasledovníkmi (die unvollkommenen Sokratiker). Z pohl'adu antiky však (ak nie všetky, tak aspoň niektoré) boli vel'mi vplyvné. Preto je označenie „malé“ pomerne diskutabilné. Neboli ani „sókratovské“ v zmysle, že by ich vznik zamýšl’al sám Sókratés. A v niektorých prípadoch neboli ani školami, ale súslednost’ou vel'mi originálnych individualít.

${ }^{8}$ Z Polykratovej strany išlo zrejme o rečnícke cvičenie, ktoré prezentuje ako reč prednesenú hlavným Sókratovým žalobcom Anytom. O Polykratovi vieme, že sa venoval žánru „paradoxných chválorečí“ (enkómia): zložil chválu Klytaimnéstry, ktorá zavraždila svojho manžela Agamemnóna; chválu král'a Búsirida, ktorí prinášal l'udské obete a dopúšt’al sa kanibalizmu; a tiež chválu Parida, ktorý únosom spartskej Heleny vyvolal trójsku vojnu (Hornblower - Spawforth - Eidinow 2012, 1176).

${ }^{9}$ K žánru sókratovských dialógov pozri Suvák 2017b, 50-56; Rossetti 1977, 11-98; Clay 1994, 23-47; Kahn 1996, 1-35; Redfield 2017, 125-138.

${ }^{10}$ Aristotelés, Poetika 1447b9-10. Okrem toho vieme, že Aristotelés sa o Sókratikoi logoi zmienil aj vo svojom stratenom dialógu $O$ básnikoch, kde sa nachádzala zaujímavá poznámka, podl'a ktorej ako prvý písal Sókratovské rozhovory istý inak neznámy Alexamenos z Teu (zl. 3 Ross). Táto poznámka by mohla dávat' lepší zmysel pri miernej úprave textu (prótús na proterús); znamenalo by to, že Alexamenos použival žáner dialógu ešte ,pred“ Sókratikoi logoi.

${ }^{11}$ Mímy boli jednoduché komické útvary, ktoré čerpali námety z bežných situácii rodinného života a používali hovorový jazyk bez metra. Sófrón bol sicílsky komédiograf, súčasník Euripida, Xenarchos bol jeho syn.

12 Redfield 2017, 125-126.

13 Porovnaj Diogenés Laertský, Životy III 47: „Vraví sa, že Zenon z Eley prvý písal dialógy. Aristoteles v 1. knihe svojho spisu $O$ básnikoch menuje [Alexamena] zo Styry alebo z Teu, ako spomína aj Favorinus vo svojich Spomienkach. Podl'a mojej mienky však Platon, ktorý priviedol tento druh písomníctva do dokonalosti, právom si zasluhuje prvenstvo, a to nielen čo sa týka krásy, ale aj vynájdenia.“ 
${ }^{14}$ Výrazným predstavitel’om takéhoto „developmentalistického“ čítania Platóna bol G. Vlastos, ktorý sa domnieval, že rané Platónove dialógy sú privilegovanou cestou k poznaniu historického Sókrata (porovnaj Vlastos 1991). Developmentalistická pozícia má aj svojich silných odporcov, ktorí prichádzajú s ,unitariánskym“ čítaním Platóna. Podla nich Platón zostavil dialógy s vopred jasnou myšlienkou, ktorú chce sprostredkovat čitatel'ovi, a preto dôležitejšou od chronológie písania dialógov je chronológia ich zamýšlaného čítania. Predstavitel'om tohto prístupu je Ch. Kahn (pozri Kahn 1994). Ani Kahn však nepopiera, že Platón bol sókratovským autorom, naopak, sókratovskú literatúru považuje za kontext, ktorý nám pomáha lepšie pochopit' Platónovu tvorbu. Súhrnný pohl’ad na Platónovu recepciu Sókrata ponúka Rowe 2006.

${ }^{15}$ Stručný súhrn Xenofóntovho obrazu Sókrata možno nájst' v Porubjak 2006; Dorion 2006; Moore 2017.

${ }^{16}$ Redfield 2017, 127.

17 Životy II 64.

${ }^{18}$ Diogenés Laertský (Životy II 85-86) uvádza dva katalógy Aristippových spisov, z ktorých niektoré boli dialógy, nevieme však, či sókratovské. Zároveň životopisec reprodukuje aj názor, že Aristippos nenapísal vôbec nič.

${ }^{19}$ Zatial' vyšli prvé tri zväzky: (1) Anitisthenove zlomky (v kratšej verzii Kalaš - Suvák 2010 a v rozšírenej Kalaš - Suvák 2013); (2) zlomky kynika Diogena (Cepko - Kalaš Suvák 2016) a (3) Aischinove zlomky (Cepko - Kalaš - Suvák 2020). Do tlače sú pripravené zlomky kynikov Kratéta a Hipparchie a plánuje sa pokračovat' komentovaným prekladom zlomkov Aristippa a kyrenaikov. Pre našu tému sú relevantné predovšetkým zväzky 1 a 3. Kynici reprezentujú generáciu po sókratovských autoroch a pre sókratovskú tradíciu myslenia sú zaujímaví svojím rozvíjaním filozofie ako životnej praxe.

20 Životy II 122-123. K Simónovi pozri Sellars 2003.

${ }^{21}$ Indíciou u Xenofónta by mohla byt' epizóda o Sókratovom rozhovore s Euthydémom v „sedlárovej dielni“" ned’aleko agory (Spomienky IV 2).

22 Diogenés Laertský, Životy II 105.

23 Tamže.

${ }^{24}$ Zaujímavý je argument, ktorý uvádza Redfield 2017, 132: Rečník Isokratés kritizuje Polykrata vo svojej reči Búsiris. Tvrdí, že Polykratés obvinil Sókrata z toho, že bol vychovávatel'om Alkibiada. Isokratés však nečakane poznamenáva (Búsiris 5), že nie je známe, že by Sókratés mal na Alkibiada nejaký vplyv. Pritom vzt’ah Sókrata a Alkibiada je častou témou v spisoch sókratovských autorov. Redfield $\mathrm{z}$ toho uzatvára, že Isokratés písal v čase bezprostredne po zverejnení Polykratovej Obžaloby a zároveň ešte nepoznal sókratovské dialógy, v ktorých figuruje Alkibiadés (pozri 5. kapitolu). To podl'a Redfielda znamená, že Isokratés napísal svojho Búsirida začiatkom 80-tych rokov 4. storočia a sókratovské spisy v tom čase ešte neboli rozšírené.

${ }^{25}$ K Antisthenovi pozri Kalaš - Suvák 2010 a 2013; Cepko 2011; Suvák 2017a.

${ }^{26}$ Môže to byt' dôvod, prečo ho Platón nezmieňuje medzi prítomnými na procese so Sókratom. 


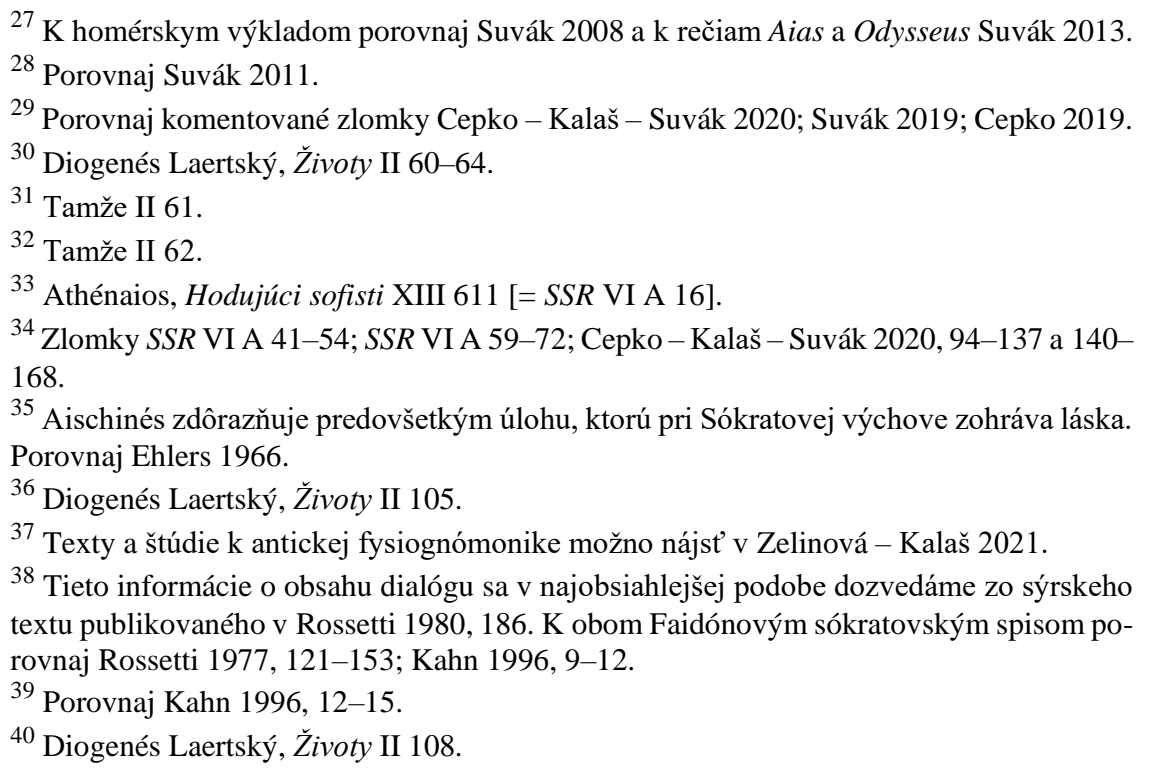




\section{Dve Obrany}

Dokial' budem dýchat' a mat'silu, neprestanem filozofovat. ${ }^{1}$

Rok 399 pred Kristom, v ktorom došlo k procesu so Sókratom a jeho poprave, priniesol so sebou, obrazne povedané, koniec Sókratovho života a začiatok jeho legendy. Ako sme ukázali v druhej kapitole, postava historického Sókrata nám do vel'kej miery uniká. Jediným nekontroverzným údajom z jeho života, žial, zostáva práve to, že bol súdený a odsúdený na smrt'. Na druhej strane to, čo malo rozhodujúci vplyv pre d'alší rozvoj filozofie v antike i za jej časovými hranicami, bol práve Sókratov odkaz recipovaný jeho poslucháčmi a transponovaný do literárnej podoby. Pozrime sa teraz na toto prelínanie historického a literárneho v súvislosti s procesom v spomenutom osudovom roku.

V Sókratovom životopise v 2. knihe Životov Diogenés Laertský cituje $\mathrm{z}$ Favorina ${ }^{2}$ pasáž $\mathrm{z}$ obžaloby, ktorá sa $\mathrm{v}$ tom čase ešte údajne nachádzala $\mathrm{v}$ aténskom štátnom archíve pri chráme Métroon, bývalom 
sídle Rady (búleutérion) na agore: „Túto žalobu podáva a prísahou potvrdzuje Meletos, syn Meletov, z dému Pithea, proti Sokratovi, synovi Sofroniskovmu, z dému Alopeky. Sokrates je vinný, pretože neuznáva bohov, ktorých uznáva štát, zavádza iné božstvá a je tiež vinný, pretože kazí mládež. Navrhuje sa trest smrti.“3 Dobové aténske súdy vyzerali úplne inak, ako sme zvyknutí v súčasnosti v našom prostredí. Neexistovali profesionálni sudcovia ani inštitút advokácie. Súdne prípady v občianskych a trestných kauzách sa rozhodovali pred početnou porotou. Tá bývala zostavená ad hoc, osobitne pre každý prípad, zo zoznamu 6 tisíc dobrovol'níkov (občanov, ktorí dovíšili 30 rokov života). Porota mohla mat' niekol'ko stoviek až tisícok členov, typicky však pät'sto. Aby sa zabránilo uplácaniu, sudcovia boli do poroty žrebovaní tesne pred konaním súdu. Členovia poroty dostávali taktiež odmenu vo výške tri oboly za deň, čo viedlo k tomu, že sa medzi dobrovol'níkov hlásili zväčša chudobní, starí a chorí občania. V 4. storočí je doložený nepárny počet sudcov (501), aby sa predišlo rovnému počtu pri hlasovaní za a proti. Či bol počet sudcov v procese so Sókratom 500 alebo 501 nie je celkom jasné. ${ }^{4}$

K obvineniu Sókrata došlo štyri roky po zvrhnutí oligarchického režimu takzvaných „tridsiatich tyranov“ a reštaurácii demokracie. Proponentmi krvavej vlády tridsiatich boli - ako bolo spomenuté - aj niektorí aténski aristokrati spájaní so Sókratom, napríklad Kritias či Charmidés. Na druhej strane hrdinom demokratickej opozície voči tomuto režimu bol garbiar Anytus, jeden z neskorších Sókratových žalobcov. Hoci vyššie citovanú žalobu podal inak nie vel'mi známy Melétos, možno predpokladat', že ,šedou eminenciou“ bol práve Anytos, ktorý pri obžalobe vystupoval spolu s istým Lykónom ako Melétov „spolupredkladatel“" (synégoros). Táto trojica - Melétos, Anytos a Lykón predniesli pred sudcami aj svoje obžalúvacie reči, z ktorých sa nám, žial', nezachovali ani len citáty z druhej ruky. V súvislosti s Anytom je zaujímavé, že ako reprezentant umiernených demokratov nechcel zbytočne vyhrocovat' situáciu a zasadil sa o prijatie amnestie na všetky zločiny spáchané počas oligarchickej vlády (výnimkou boli samotní „Tridsiati“). 


\section{Dve Obrany}

Prostredníctvom tohto kroku si demokrati sl’ubovali čo najrýchlejšie konsolidovanie pomerov. ${ }^{5}$ Proces so Sókratom je v tomto kontexte vel'kou záhadou, a to najmä preto, že končí rozsudkom smrti. Na druhej strane tento kontext pomáha objasnit' povahu vznesených bodov obžaloby. Ak Sókratés bol naozaj považovaný za hrozbu pre obec, pretože okolo seba zoskupoval demokracii nepriatel'ské živly, vzhl'adom na trvajúcu amnestiu nebolo naňho možné aplikovat' žalobu, ktorá by mala politickú povahu. Siahlo sa preto po obvinení z bezbožnosti ( grafé asebeias), ${ }^{6}$ hoci v pozadí mohol byt' nevyslovený politický motív spojený s objednávkou zbavit' sa raz a navždy nepohodlného Sókrata a zastrašit' jeho oligarchicky zmýšl'ajúcich sympatizantov. $^{7}$

V prípadoch spojených s náboženstvom sa obvinený musel najskôr dostavit' $\mathrm{k}$ predbežnému vypočutiu pred archóntom basileom. Úlohou tohto vysokého štátneho úradníka bolo rozhodnút', či prípad spĺn̆a náležitosti potrebné k tomu, aby sa s ním mohlo predstúpit’ pred súd. Sókratovo čakanie na tento predbežný výsluch tvorí kontext, do ktorého Platón vsadil rozhovor s kňazom Euthyfrónom v rovnomennom dialógu. Archón basileus predsedal aj samotnému procesu. Ked’že v tej dobe súčast'ou súdneho konania nebolo dokazovanie, úlohou predsedajúceho bolo iba dozriet' na to, aby v správnom poradí odzneli reči žalujúcej a obvinenej strany, aby obidve strany neprekročili im vyhradený čas a aby nedošlo k prípadným narušeniam poriadku. Proces sa začínal ráno a musel byt' ukončený do západu slnka toho istého dňa. Predpokladá sa, že predpoludnie patrilo žalobcom a ich svedkom, popoludnie obvinenej strane a jej svedkom. Ked’že pred súdom neexistovalo právne zastupovanie, reč musela každá strana i ich svedkovia predniest' osobne, sami za seba. To však nebránilo tomu, aby si reč nedali vypracovat’ profesionálnemu ,pisatel'ovi rečí", logografovi. ${ }^{8}$

Súdne kauzy v Aténach boli v tom čase dvojakého druhu: bud' išlo o kauzu typu grafé, pri ktorej hociktorý občan mohol predniest' žalobu na porušenie spravodlivosti, alebo o kauzu typu diké, kedy žalobu prednášala samotná obet' údajného zločinu (alebo jej najbližší mužský príbuzný). Sókratova kauza bola prvého typu. ${ }^{9}$ Kauzy typu grafé sa znova delili na dve 


\section{Dve Obrany}

skupiny: bud' k nim zákon pripájal vopred stanovenú sankciu, alebo o tom, aká bude sankcia rozhodovali sudcovia, čo bol aj prípad Sókratovej kauzy. V tomto druhom prípade sa postupovalo tak, že súd najprv rozhodol hlasovaním prostou väčšinou o vine alebo nevine, a potom - v prípade viny - rozhodoval o forme trestu. Trest navrhla najskôr obžaloba, a potom, po rozhodnutí o vine, si trest navrhla aj obžalovaná strana. Súd napokon hlasovaním prostou väčšinou rozhodol, či sa aplikuje trest navrhnutý žalujúcou alebo obžalovanou stranou. ${ }^{10}$

Tol'ko $\mathrm{k}$ historickému pozadiu aténskych súdnych procesov. Ako vyzeral samotný súd so Sókratom, nemáme priame informácie. Poznáme jeho výsledok - Sókratés bol odsúdený na smrt'. Pokial' ide o prednesené reči obžaloby a obvineného, musíme sa spol'ahnút' na správy z druhej ruky. Ako sme spomenuli v predošlej kapitole, s odstupom niekol'kých rokov po procese sa objavila fiktívna reč (Katégoria) žalobcu Anyta, ktorú napísal rečník Polykratés. Tá sa nám síce nezachovala, no zachovali sa nám reakcie zo strany Sókratových sympatizantov v podobe Sókratovej obrany. V úplnosti máme $\mathrm{k}$ dispozícii dve z nich - od Platóna a Xenofónta. ${ }^{11}$ Druhý menovaný na začiatku svojho spisu tvrdí, že takýchto obrán (a možno aj „obžalôb“) kolovalo v tom čase viacero. ${ }^{12} \mathrm{Na}$ druhej strane nenachádzame $\mathrm{v}$ Xenofóntovom texte jednoznačnú oporu, ktorá by nám dovolila predpokladat', že Xenofón poznal text Platónovej Obrany. Je preto nel'ahké stanovit', ktorá z dvoch nám známych Obrán bola napísaná skôr. ${ }^{13}$ Pokial' ide o Xenofóntom zmienených „iných“ autorov, do úvahy by okrem Platónovho diela prichádzala obhajobná reč, ktorú údajne ponúkol Sókratovi rečník Lysias, ${ }^{14}$ prípadne možno uvažovat' o tom, či za takýchto strážcov tradície o Sókratovom správaní pred súdom Xenofón nepovažoval svoje dva zdroje - Hermogena a Apollodóra. ${ }^{15}$

Zostaňme však pri dvoch Obranách, ktoré sa nám zachovali vo svojej celistvosti. V obidvoch prípadoch ide o zmes autentických spomienok a fikcie, ktorá sleduje viacero zámerov: ukázat' Sókrata pred Aténčanmi v dobrom svetle, pripomenút' Sókratovým sympatizantom, v čom spočívala hodnota Sókratovho pôsobenia, a nájst' dôvody, prečo došlo k takému tvrdému rozsudku a trestu a prečo sa Sókratés tomuto výsledku podvolil. 


\section{Dve Obrany}

Z oboch spisov si z perspektívy nášho záujmu zaslúži viac pozornosti Obrana od Platóna. V porovnaní so Xenofóntovou verziou je obšírnejšia, štylizovaná (podobne ako Polykratova Obžaloba) ako reč, ktorá zaznela (alebo prinajmenšom mohla zazniet') pred sudcami a korešponduje s dobovými reáliami aténskych súdnych procesov. Okrem toho, Platón sám o sebe píše, že sa súdu osobne zúčastnil. ${ }^{16}$ Na rozdiel od neho Xenofón bol v tom čase mimo Atén na svojom maloázijskom dobrodružstve a vo svojej Obrane sa ani nesnaží predstierat', že by patril medzi očitých svedkov.

Platónova Obrana je štruktúrovaná do troch častí odvíjajúcich sa od jednotlivých fáz súdneho procesu. V prvej časti (17a-35d) zaznieva Sókratova obhajobná reč v užšom zmysle slova. V porovnaní so zvyšnými dvoma čast'ami je najdlhšia. Z kontextu sa dozvedáme, že Platónov Sókratés sa ujíma slova potom, ako dozneli reči jeho žalobcov. Na začiatku a konci Platón imituje dobové konvencie žánru súdnych rečí (rečník tvrdí, že bude hovorit' pravdu, zatial' čo druhá strana klame; okrem toho apeluje u sudcov na cit pre spravodlivost'; priznáva sa k neobratnosti vo vyjadrovaní; v závere tvrdí, že nebude na sudcov vyvíjat' emocionálny tlak, ale spolieha na ich nestrannost' a vernost' zloženej prísahe). Jadro Sókratovej prvej reči je venované vyvráteniu jednotlivých troch bodov obžaloby: údajnej bezbožnosti, neúcty voči božstvám obce a zlému výchovnému vplyvu. Začína úvahou nad príčinami antipatií, za ktoré môže nielen trojica aktuálnych žalobcov, ale už dlhšiu dobu pôsobiaca fáma o tom, že Sókratés je „,múdry muž“ (18b). Menovite za šírenie tejto fámy môže Aristofanés (19c). Hoci sa môže zdat', že označit' niekoho za „múdreho“ predsa nie je znakom „zlej povesti“, v kontexte obvinenia z bezbožnosti bolo skúmanie ,vecí pod zemou a vecí nebeských“vnímané ako prejav arogancie a pýchy (hybris), prekračovania hraníc určených smrtel'níkom. Tu Platónov Sókratés predstavuje sudcom príbeh svojho života, ktorý je naopak v znamení jasného vedomia o hraniciach l'udskej kompetencie. Za chýr o Sókratovej múdrosti môže výrok delfskej veštiarne, ktorá na otázku Sókratovho priatel'a Chairefónta, či je niekto 


\section{Dve Obrany}

múdrejší od Sókrata, odpovedala v zmysle, že nikto nie je od neho múdrejší (21a). ${ }^{17}$ Výrok veštiarne, ktorého autorom mal byt' sám boh Apollón a tlmočníčkou Pýthia, Sókratés považuje za dôveryhodný, no na druhej strane je v príkrom rozpore so Sókratovým presvedčením o vlastnej nevedúcnosti. Sókratés sa preto rozhodne podrobit' výrok veštiarne testu: ak nájde aspoň jedného človeka, ktorý je múdrejší od neho samého, ukáže sa, že jeho osobné presvedčenie je správne a veštiareň sa mýli. Preto za svoju osobnú životnú misiu prijme testovanie múdrosti tých, čo sú za múdrych bežne považovaní. Ukazuje sa však, že múdrost' týchto „múdrych“ je len domnelá. Sami sa o sebe nazdávajú, že sú múdri, no túto svoju múdrost' nevedia zdôvodnit'. Na rozdiel od nich, Sókratés sa ani len nedomnieva, že je múdry a toto ho robí autentickejším od ostatných. ${ }^{18}$ Tento štýl života, ktorý nazýva filozofovaním (filosofein) mu priniesol vel'a nepriatel'stiev a doviedol ho v konečnom dôsledku pred súd. Považuje ho však za úlohu od boha, ktorého výrok sa mu za celý život nepodarilo vyvrátit'. Sókratova paradoxná „múdrost““ je teda podl'a neho službou bohu a zároveň príčinou, prečo stojí pred súdom obvinený z bezbožnosti. Ide však aj o službu rodnej obci a v tomto zmysle filozofia koinciduje s výchovnou misiou: Sókratés nie je ten, kto Aténčanov kazí, ale ten, kto ich svojím skúmaním robí lepšími. Jeho činnost' je iste nepríjemná ako uštipnutie ovada, ale práve vd'aka nej obec napreduje (30e). Vyvracanie domnelej múdrosti je zároveň etickým apelom odvrhnút' falošné hodnoty (,,peniaze, slávu a pocty“) a usilovat' sa o hodnoty pravé - ,rozumnost', pravdu a dušu“ (29e). Filozofia je tak v prvom rade starostlivost'ou o dokonalost' duše, to, čo robí jednotlivca lepším v etickom zmysle, to, v čom spočíva jeho cnost' (aretê). V tomto zmysle je prvá obhajobná reč Platónovho Sókrata zaujímavým dokumentom problému súvislosti medzi poznaním a cnost'ou. Odkrýva sókratovský posun v chápaní cnosti (od blahobytu a moci k etickej dokonalosti) ako aj posun v chápaní poznania (od básnického poznania inšpirovaného bohmi a sofistického všeobsiahleho vzdelania k skúmaniu bežných názorov a približovaniu sa $\mathrm{k}$ pravde prostredníctvom očist'ovania sa od mienok, ktoré sú falošné). Je to zároveň text, v ktorom sa prejavuje 


\section{Dve Obrany}

niečo, čo by sme mohli nazvat' paradoxom Platónovho Sókrata: ${ }^{19}$ (1) Sókratés je vykreslený ako paradigma cnosti; (2) Sókratés tvrdí, že cnost' spočíva v poznaní; (3) Sókratés tvrdí, že nemá poznanie. Ak z tohto súboru výrokov vyberieme ktorékol'vek dva, zdá sa, že ten zvyšný nie je s nimi konzistentný. Únik z tejto trilemy ponúkajú rozlíšenia, ktoré Sókratés predostiera práve v Platónovej Obrane: rozlíšenia medzi múdrostou, ktorú má boh, a tou, ktorou disponujú l’udia. Tá druhá, hoci je v porovnaní s prvou „bezcenná“, pripúšt’a stupňovanie. Sókratov „náskok“ pred ostatnými l’ud'mi je v tom, že si na jednej strane bolestivo uvedomuje (epistemologický rozmer), že je ešte d'aleko od méty, no na druhej strane vyvíja úsilie (etický rozmer), ako sa stále viac zdokonal'ovat'.

Druhá Sókratova reč v Platónovej Obrane odznieva v čase, ked’ sudcovia tesnou väčšinou odhlasovali Sókratovu vinu. V tejto fáze procesu v kauze, pri ktorej zákon nepredpisoval sankciu, si odsúdený mal navrhnút' trest, ktorý sa nemusel zhodovat's trestom navrhnutým obžalobou. Konzistentne s presvedčením o vlastnej nevine si Sókratés najprv odmieta navrhnút' skutočný trest a hovorí, že za svoju činnost' prospešnú obci by si skôr zaslúžil odmenu - stravovanie na verejné útraty (36d-e). Nakoniec však ustupuje (možno aby dodržal literu zákona, podl'a ktorej bolo na ňom, aby si stanovil trest, o ktorom by sa potom hlasovalo) a vyberá si peňažnú pokutu. Najprv skromnú - jednu mínu striebra, ktorú by zo svojho skromného majetku mohol sám zložit' - potom vyššiu, v hodnote tridsat' mín, s ktorou by mu vypomohli priatelia.

Napokon posledná, tretia reč pred sudcami, je situovaná do momentu po hlasovaní, či bude aplikovaný trest, ktorý navrhla obžaloba, alebo ktorý si navrhol odsúdený. Sudcovia hlasovali za trest smrti. Nemáme indície o tom, či takáto reč bola pri aténskych súdnych procesoch bežnou praxou. Z procesuálneho hl'adiska už nemala vel'ký zmysel, pretože o všetkom už bolo rozhodnuté a vyjadrenie odsúdenca už na výsledku nemohlo nič zmenit'. Platón však využíva tento priestor na to, aby vyjadril nádej, že ako sa Sókratés počas celého života snažil o čo najlepší život, ani smrt' dobrého človeka nemôže byt' zlom. Považovat' smrt' za zlo znamená mat' istotu o niečom o čom istotu mat' nemôžeme. Sókratov postoj 


\section{Dve Obrany}

k smrti je v tomto zmysle dôsledným aplikovaním princípu, podl’a ktorého sa nedomnieva, že vie niečo, čo v skutočnosti nevie. Platón necháva svojho Sókrata vyjadrit' dôvody, ktoré poukazujú skôr na to, že pre neho samého je smrt' dobrom: hlas, ktorý ho v živote odvracal od zlého, ho neodvrátil od toho, aby sa dostavil pred súd. A napokon v otázke toho, či je smrt' dobro alebo zlo, konštruuje dilemu, ktorej výsledok je dôvodom k nádeji. Nech je smrt' bezsenný spánok, alebo prest'ahovanie sa na iné miesto, Sókratés obe možnosti považuje za dobré.

Pokial' ide o Xenofóntov spis s názvom Obrana Sókratova, ten má vel'mi odlišnú povahu. ${ }^{20}$ Ako bolo povedané vyššie, Xenofón bol v čase súdu so Sókratom mimo Atén a pri písaní sa ani nesnaží budit' dojem, že bol osobne pri tom. Využíva svedectvá z druhej ruky a rozširuje aj kontext: nereprodukuje iba Sókratove vyjadrenia pred sudcami (táto centrálna pasáž tvorí len približne dve tretiny textu - Obrana 10-26), ale uvádza aj Sókratove myšlienky, s ktorými sa zveril svojim priatel'om pred konaním procesu a po ňom. Xenofóntovým zámerom je objasnit', prečo napriek tomu, že Sókratés býval vo svojich diskusiách taký presvedčivý, súd dopadol tak, ako dopadol. Xenofóntovo vysvetlenie je také, že sám Sókratés si smrt' prial a preto použil súd ako nástroj k tomu, aby ju dosiahol. Odmietol pripravit' si reč odvolajúc sa na to, že jeho prípravou bol celý jeho život. Uvádza, že ho k tomu viedol vnútorný hlas, daimonion. Preto pri súde vystupoval povýšenecky a provokatívne. Sókratova smrt' teda bola akceptovanou nevyhnutnost'ou, zavíšením života naplneného múdrost'ou a spravodlivost'ou.

\footnotetext{
${ }^{1}$ Platón, Obrana 29d.

${ }^{2}$ Favorinus z Areláty bol rímsky vzdelanec z prvej polovice 2 . storočia po Kristovi.

3 Životy II 40.

${ }^{4}$ Nails 2002, 268-269.

${ }^{5}$ Brickhouse - Smith 2000, 27-28.
} 
${ }^{6}$ Okolo roku 432 pred Kristom bol v Aténach prijatý takzvaný Diopeithov dekrét, ktorý umožňoval vznášat' žalobu za bezbožnost'. Dekrét bol pravdepodobne namierený proti Anaxagorovi. Zločinu sa podl'a neho dopúšt’al ten, kto „,neveril v božstvá a vyučoval o nebeských veciach“ (Plútarchos, Periklés 32,1). Osoby reálne obžalované z bezbožnosti boli vo väčšine prípadov zbavené viny, alebo sa zachránili útekom, s výnimkou dvadsat’dva popravených v prípade poškodenia hermoviek v roku 415. Dokonca tesne pred Sókratom bol v roku 400 alebo 399 zbavený viny aj rétor Andokidés. Navyše, amnestia z roku 403 Diopeithov dekrét anulovala. Ak sa Melétos spoliehal na to, že obvinenie z bezbožnosti zaúčinkuje na porotcov, musela verejnost' $\mathrm{v}$ tom čase takýto postoj vo veci náboženstva považovat' za niečo šokujúce (Brickhouse - Smith 2004, 188, pozn, 47; Filonik 2013).

${ }^{7}$ Bežne sa pozeráme na proces so Sókratom cez prizmu správ od jeho prívržencov a vnímame Sókrata ako nevinnú obet'. $Z$ opačnej perspektívy sa na celý problém pozerá Montuori 1998, ktorý sa snaží pochopit', prečo obec mohla oprávnene Sókrata považovat' za nebezpečnú osobu.

${ }^{8}$ Diogenés Laertský sa zmieňuje o tom, že Sókratovi mal ponúknut obhajobnú reč známy rečník Lysias. Sókratés ju však odmietol (Životy II 40). Platónov Sókratés v Obrane tvrdí, že nebude krasorečnit', ale prednesie iba prostú, nezdobenú reč (17b). U Xenofónta zas hovorí o tom, že si žiadnu reč nepripravoval, lebo celý jeho život bol prípravou na vystúpenie pred súdom (3).

${ }^{9}$ Porovnaj Platón, Euthyfrón 2b, kde Sókratés hovorí, že sa nikdy nestretol s mládencom, ktorý ho žaluje.

${ }^{10}$ Brickhouse - Smith 2004, 72-73.

${ }^{11}$ Preklad Platónovej Obrany je možno nájst' v súborných prekladov Platónovho korpusu od F. Novotného (v češtine) a J. Špaňára (v slovenčine). Preklad Xenofóntovej Obrany je dostupný v českom preklade V. Bahníka (Xenofón 1972, 229-242) a v slovenskom preklade od A. Kalaša (v dvojjazyčnej edícii Xenofón 2006, 149-173).

${ }^{12}$ Xenofón, Obrana 1. Spisy pod názvom Obrana Sókratova sa pripisujú aj pomerne vel'kému počtu neskorších autorov: Isokratovmu žiakovi Theodektovi z Fasélidy, Démétriovi z Faléra, Theónovi z Antiochie, Plútarchovi a Libaniovi (Guthrie 1975, 73).

${ }^{13}$ K diskusii o čase napísania Platónovej Obrany porovnaj Guthrie 1975, 71-72.

${ }^{14}$ Porovnaj vyššie poznámka 8 .

${ }^{15}$ Xenofón, Obrana 2-9 a 28. Redfield 2017, 128 považuje týchto dvoch za „tichých spoločníkov“" pri zrode žánru Sókratikoi logoi.

${ }^{16}$ Dvojnásobný výskyt mena „Platón“v Obrane (33e a 38b) je v rámci celého súboru Platónových spisov ojedinelý zjav. Okrem Obrany Platón sám o sebe píše (s výnimkou Listov) už iba vo Faidónovi, kde signalizuje, že pri rozhovoroch posledného Sókratovho dňa nebol prítomný, pretože bol chorý (Faidón 59b).

${ }^{17}$ Historickost príbehu o Chairefóntovej návšteve veštiarne a Pýthiinej odpovedi má medzi modernými odborníkmi svojich zástancov i pochybovačov (k diskusii porovnaj Guthrie 1971b, 86). Platónova Obrana obsahuje dva varianty odpovede, citovanú negatívnu odpoved’ „nikto nie je múdrejši““ (21a) a pozitívne vyjadrenie, ktoré sa objavuje 
v Sókratovej úvahe nad zmyslom veštby „čo teda tým asi myslím, ked' hovorí, že som najmúdrejšsi“ “ (21b). Druhý variant predstavuje silnejšie tvrdenie, ktoré naozaj Sókratovi pripisuje nejakú formu múdrosti. Prvý, negatívny variant, je zas konformnejší so Sókratovým rezervovaným postojom v otázke vlastného vedenia: Sókratés by v tomto prípade mohol byt' rovnako „nemúdry“ ako všetci ostatní. Xenofóntova verzia má negatívnu formu, no okrem múdrosti sa týka aj d'alších dvoch vlastností, ked' o Sókratovi hovorí, že nikto z l'udí nie je ani slobodnejší, ani spravodlivejší, ani umiernenejší (Obrana 14-15). V poznámke (scholiu) k Aristofanovým Oblakom 144 neznámy antický komentátor uvádza takéto znenie veštby: „Sofoklés je múdry, Euripidés múdrejší, no zo všetkých l'udí najmúdrejší je Sókratés“.

18 Toto uvedomenie si vlastnej nevedomosti vyjadril neskôr Cicero, ked' o Sókratovi napísal, že ,jediná vec, ktorú vie, je to, že nič nevie“ (ipse se nihil scire id unum sciat; Akademika I 16). Často citované zl'udovené heslo pripisované Sókratovi - „Viem, že nič neviem“ - hoci mu nechýba rétorický pátos, je v skutočnosti paralogizmus, výrok, ktorý vyvracia sám seba. Vyjadrenie v Platónovej Obrane je ovel'a opatrnejšie: „Ja však tak ako skutočne nič neviem, ani si nenamýšl'am, že niečo viem“ (21d).

${ }^{19}$ Porovnaj Vlastos 1971; Smith 2018.

${ }^{20}$ Bližšie k rozdielom medzi Platónovou a Xenofóntovou Obranou porovnaj Danzig 2010, 19-69. 


\section{Prípad Alkibiadés}

Musime obidvaja uvažovat' o tom, akým spôsobom by sme sa stali čo najlepšimi. ${ }^{1}$

Videli sme, že v obhajobe vlastného života pred aténskymi sudcami Platónov Sókratés kladie svoje úsilie o porozumenie sebe samému do úzkeho vzt’ahu s vychovávatel'skou misiou: Sókratés je ten, kto „filozofuje“ testujúc názory domnelých múdrych, a zároveň povzbudzujúc a napomínajúc druhých, aby sa starali o to, čo má skutočnú hodnotu: „Chodím totiž po obci a nerobím pritom nič iné, len presviedčam mladých i starých, aby sa v prvom rade a tak usilovne nestarali ani o telo, ani o peniaze ako o dušu, aby bola čo najlepšia.“2 „Stat' sa čo najlepším“ je len iný výraz pre „starostlivost' o seba“, ktorá je v perspektíve sokratiky podstatou filozofie, a to nielen vo vzt'ahu k sebe samému, ale aj vo vzt'ahu k druhým. Stávat' sa lepším nemožno izolovane, ale iba spolu s druhými, pretože ide o úsilie viazané na skúmajúci rozhovor. Sókratovo filosofein má teda dve roviny - skúmanie toho, čo kto hovorí, a súčasne skúmanie životov, charakterov spoludiskutujúcich osôb. ${ }^{3}$ Hoci apel stávat' sa lepším adresuje Sókratés 
bez výnimky všetkým, „starým i mladým“, spontánne sa okolo neho zhromažd’uje predovšetkým mládež, ktorá s pobavením pozoruje jeho výmeny otázok a odpovedí s domnelými znalcami. ${ }^{4}$ Tento vplyv na mládež je tiež jedným z dôvodov, prečo Sókratés musí čelit’ súdu.

Kameňom úrazu a možnou nevypovedanou čast'ou obžaloby mohlo byt' to, že táto ,zlatá“ aténska mládež zoskupujúca sa okolo Sókrata pochádzala z vel'kej časti $\mathrm{z}$ aristokratických kruhov a vyznačovala sa filospartskými tendenciami. ${ }^{5}$ Existujú indície, že Polykratov pamflet $O b$ žaloba Sókrata vyniesol toto skryté obvinenie na svetlo a ústami Anyta kládol Sókratovi za vinu, že mal zhubný vplyv na kontroverznú postavu aténskych politických a vojenských dejín - Alkibiada. ${ }^{6} \mathrm{O}$ tom, že Polykratés zat'al do živého, svedčí živý záujem o túto tému medzi sókratovskými autormi a ich úporná snaha vysvetlit', že Alkibiadov príbeh nebol výsledkom Sókratovej výchovy, ale práve naopak, výsledkom toho, že Alkibiadés sa od určitého momentu so Sókratom prestal stretávat'. Podl'a sókratovcov teda Alkibiadovou skazou nebol Sókratov vplyv, ale prerušenie tohto inak blahodarného vzt'ahu. Okrem toho téma vzt'ahu Sókrata a Alkibiada slúži pre autorov sókratovskej literatúry ako prípadová štúdia Sókratovho modelu výchovy.

Skôr než sa pozrieme na stvárnenie tohto výchovného vzt'ahu v sókratovskej literatúre, venujme aspoň krátky priestor historickej osobe Alkibiada. Kto bol tento Sókratov obl'úbenec a prečo jeho osobnost' ešte dlho vzbudzovala v Aténach vášne a rozpaky? ${ }^{7}$

Alkibiadés (451-404 pred Kristom) pochádzal po otcovi Kleiniovi aj matke Deinomaché z dvoch aténskych rodov, ktoré sa vyznačovali majetkom a vplyvom. Po právnej stránke bol sirotou od svojich šiestich rokov, ked' v bitke pri Koronei (447 pred Kristom) zomrel jeho otec. Odvtedy, zrejme na žiadost' vyjadrenú ešte za živa jeho otcom, sa o chlapcovu výchovu staral bratanec jeho matky, známy štátnik Periklés, hoci formálne si ho neosvojil (preto si Alkibiadés zachoval pôvodné meno podl'a dému Skambonidai). Platón ${ }^{8}$ píše, že mladý vojak Alkibiadés bojoval v bitke pri Poteidai (432 pred Kristom) v tom istom oddiele ako 


\section{Prípad Alkibiadés}

Sókratés. Vtedy vraj starší hoplita zachránil život i zbroj zraneného Alkibiada. Za tento hrdinský čin však velitelia neodmenili Sókrata, ale rozhodli sa vyznamenat' práve mladíka, vzhl'adom na jeho pôvod a bohatstvo. So Sókratom sa ocitol aj v bitke pri Déliu (424 pred Kristom), kde Alkibiadés bol už jazdcom. ${ }^{9}$ Neskôr sa vypracoval na zdatného velitel'a a presvedčivého rečníka. Známym sa stal aj ako vít’az viacerých športových hier, nie však vd’aka osobnej účasti, ale vd’aka tomu, že vlastnil kone pretekajúce vo finančne najnáročnejšej disciplíne - sútaži štvorzáprahov. Svoje bohatstvo bez škrupúl' dokázal využit' na budovanie vplyvu, ponižovanie protivníkov a vzbudzovanie obdivu voči vlastnej osobe. V roku 415 presvedčil aténske zhromaždenie, aby s obrovskou flotilou vyplávali proti Syrakúzam, a sám sa usiloval dostat' do jej čela. ${ }^{10}$ Sicílska výprava mala Aténam zaistit' zásobovaciu cestu, ktorú v tom čase vážne ohrozovala Sparta, no napokon skončila katastrofou. Tesne pred jej začiatkom sa v Aténach udiali dva svätokrádežné incidenty: zničenie hermoviek v priebehu jedinej noci (hermovky boli stĺpy s Hermovými bustami, ktorými sa v Attike značili hranice súkromných a verejných pozemkov) a parodovanie eleusinských mystérií $\mathrm{v}$ súkromných domoch bohatej a rozpustilej aténskej mládeže, pričom prvý incident viedol k odhaleniu druhého. Zatial' čo zničenie hermoviek mohli mat' na svedomí občania, ktorí boli proti výprave a chceli zneuctením boha bezpečného cestovania odhovorit' Aténčanov od plavby, do urážlivých výčinov bujarej mládeže mal byt' zapletený aj Alkibiadés, ktorého napokon stihla žaloba z hanobenia mystérií. Súd sa mal konat' až po odchode expedície a Alkibiada vyzvali, aby opustil flotilu a predstúpil pred súd za bezbožnost'. Ten však utiekol a dezertoval do Sparty, načo bol v Aténach odsúdený v neprítomnosti. Na úteku spolupracoval tak so Spart’anmi, ako aj Peržanmi, a to až do pádu aténskej oligarchie $\mathrm{v}$ roku 411 pred Kristom. $\mathrm{V}$ tom čase aténski velitelia na Hellesponte Alkibiada požiadali, aby sa vrátil a prevzal velenie flotily pri ostrove Samos. Proti tomu sa však postavili rodiny Eumolpidov a Kerykov, ktoré boli dedične poverené spravovaním eleusinských mystérií. ${ }^{11}$ Nasledovalo obdobie úspechov v námorných bitkách, no rodnému mestu 


\section{Prípad Alkibiadés}

sa Alkibiadés vyhýbal. Atény ho prijali až v roku 408, ked’ ho bez akýchkol'vek námietok rehabilitovali a dostal aj náhradu za skonfiškovaný majetok. S nadšením ho vyhlásili za najvyššieho stratéga s absolútnymi právomocami a ako prejav vd'aky zorganizoval pešiu pút' vojska do Eleusiny. Po prehratej námornej bitke pri Notiu sa priazeň Aténčanov od Alkibiada znova odvrátila a on sa utiahol na svoj statok na thráckom Chersonése (súčasný polostrov Gallipoli). O jeho smrti v roku 404 máme rozporuplné informácie. ${ }^{12}$ Podl'a jednej verzie ho na žiadost' Spart'anov zajal a dal zabit' perzský satrapa Farnabaz, alebo, podl'a inej verzie, zahynul v šarvátke s vojakmi vedenými satrapovým bratom a strýkom. ${ }^{13}$

Alkibiadés sa nedožil oligarchického prevratu, ked' Kritias so skupinkou „Tridsiatich“ prevzali v roku 404 v Aténach moc. Zomrel v tom istom roku mimo Atén. Možno len špekulovat’ o tom, či by sa v novej situácii nevrátil do vlasti a nestal sa jedným z hlavných predstavitel'ov krutovlády. Isté však je, že rovnako ako niektorí predstavitelia tohto režimu, aj Alkibiadés patril do krúžku mladíkov združených okolo Sókrata, dokonca Sókratés mu prejavoval mimoriadnu náklonnost' a orientoval naňho svoje výchovné úsilie. Vzt'ah medzi Sókratom a Alkibiadom sa u sókratovských autorov stal oblúbenou témou, na ktorej sa snažili vyjadrit’ povahu Sókratovho výchovného pôsobenia. Ide o motív, ktorému venovali svoje spisy bez výnimky všetci autori Panaitiovej ${ }^{14}$ „kánonickej šestice“. Dialógy pod názvom Alkibiadés sa objavujú v katalógoch spisov Faidóna, ${ }^{15}$ Eukleida, ${ }^{16}$ Antisthena, ${ }^{17}$ Aischina ${ }^{18}$ aj Platóna. ${ }^{19}$ Výnimkou je Xenofón, u ktorého však možno nájst' Sókratov rozhovor s Alkibiadom v Spomienkach na Sókrata. ${ }^{20}$

Pozrime sa bližšie na zlomky z Antisthenovho a Aischinovho Alkibiada a na obsah Platónovi pripisovaného dialógu Alkibiadés Väčší, ktorý sa nám zachoval v úplnosti, a všímajme si, ako jednotliví autori chápu Sókratovo výchovné pôsobenie. Najmenej št’astia máme v prípade Antisthenovho spisu, z ktorého sa nám zachovalo niekol'ko zlomkov, ktoré neprezrádzajú obsah, ale upozorňujú na protiklad medzi Sókratom a Alkibiadom. Antisthenés zdôrazňuje Alkibiadovu fyzickú krásu, ktorá podl'a neho súperí s krásou hrdinu Achilla. Na druhej strane Alkibiadovo 


\section{Prípad Alkibiadés}

vnútro nie je ani zd’aleka také krásne, ako jeho zovňajšok: mládenec je násilný a chýba mu výchova. ${ }^{21}$ Mladý, krásny, no arogantný Alkibiadés je akoby prevráteným obrazom staršieho Sókrata, ktorý navonok vyzerá komicky, no vyznačuje sa vnútornou krásou, pretože sa stará o svoj morálny charakter. ${ }^{22}$ Je vel'mi pravdepodobné, že Antisthenés poznal Alkibiada osobne, a zdôrazňovanie mládencovej fyzickej krásy zrejme slúžilo na to, aby upriamil pozornost' čitatel'a na kontrast medzi prítažlivým vonkajším zdaním a odpudivou realitou jeho vnútorného charakteru. O Sókratovom výchovnom pôsobení na ambiciózneho mladíka sa však zo zachovaných zlomkov nedozvedáme nič určité. Vieme, že Antisthenés písal (podobne ako Platón) aj o tom, ako Sókratés prispel k tomu, že velitelia vyznamenali Alkibiada za udatnost' $\mathrm{v}$ boji. ${ }^{23}$

$\mathrm{Z}$ dialógu Alkibiadés od sókratovca Aischina sa nám zachovalo viacero obsiahlejších zlomkov, vd’aka čomu je Aischinés po Platónovi a Xenofóntovi tretím nám najlepšie známym sókratovským spisovatel’om, pokial' ide o rozsah zachovaného materiálu, hoci za oboma výrazne zaostáva. Zlomky nám umožňujú do určitej miery rekonštruovat' aj obsah samotného dialógu. O Alkibiadovom fyzickom vzhl’ade Aischinés na nám známych miestach mlčí a sústred’uje sa na opis mladíkovho vnútra. Opisuje ho ako pyšného a povýšseneckého človeka schopného pohŕdat' aj vlastným pestúnom Periklom, ba dokonca aj dvanástimi olympskými bohmi. ${ }^{24}$ Aischinés dokonca hovorí, že mládenec bol postihnutý „,chorobou“ charakteru. Sókratés sa s mládencom stretáva v gymnáziu Lykeion a dáva sa s ním do reči. Tá však neprebieha sériou otázok a odpovedí, ako sme zvyknutí u Platónovho Sókrata. Aischinov Sókratés kladie pred oči dospievajúceho ambiciózneho Alkibiada príklad jedného z najobdivovanejších aténskych stratégov, vít'aza nad Peržanmi, Themistokla. Ciel'om je vystupňovat' v mladíkovi ,žiarlivost"“ na Themistokolove úspechy. Táto žiarlivost' má spôsobit' terapeutický šok v podobe uznania vlastnej nedostatočnosti a úbohosti. Alkibiadés nakoniec prepuká v plač a prosí Sókrata, aby mu pomohol stat' sa lepším, čiže dosiahnut' areté. Zaujímavý je záverečný komentár Aischinovho Sókrata, ktorý vyslovuje pravdepodobne už v Alkibiadovej neprítomnosti, v spätnom zamyslení sa nad 
obsahom ich rozhovoru: Sókratés priznáva, že nemá „znalost““ (technê), vd'aka ktorej by automaticky dokázal druhých robit' lepšími. Ak sa mu to niekedy podarí, je to dielo nevyspytatel'ného „božieho údelu“ (theia moira). Jediným Sókratovým vedomým vkladom do jeho vychovávatel'ského diela je „láska“ (erós) a „spoločenstvo“ (syneinai). ${ }^{25}$

Úvahou o rozdiele medzi láskou v zmysle fyzickej prít’ažlivosti a láskou ako záujmom o to, aby milovaná osoba bola čo najlepšou, sa začína aj dialóg Alkibiadés Väčší, ktorý sa nám na rozdiel od dvoch vyššie zmienených diel zachoval kompletný. Tradične je pripisovaný Platónovi, no o jeho autorstve niektorí moderní kritici vyslovili pochybnosti, zatial' čo iní argumentujú v prospech Platónovho autorstva. ${ }^{26}$ Či už ho napísal sám Platón, alebo niektorý z akademikov ešte za Platónovho života alebo v období tesne po jeho smrti, nás nemusí pri našom skúmaní až tak trápit'. Každopádne ho totiž možno považovat' za vydarený kúsok platónsky interpretovaného sókratovského povzbudenia $\mathrm{k}$ starostlivosti o seba, a teda za súčast' sókratovskej literatúry. V neskorej antike sa tento dialóg tešil vel'kej vážnosti a niektorí gramatici a novoplatónski systematici ho odporúčali čítat' ako úvod do Platónovej filozofie. ${ }^{27}$

Alkibiadés je vo veku, ked’ má za sebou formálnu výchovu a vstupuje do sveta mužov s politickými ambíciami. Je teda vo veku okolo dvadsiatky. Sókratés mu v úvode vysvetluje, prečo sa mu doteraz vyhýbal: zakazoval mu to jeho vnútorný hlas (daimonion), aby jeho záujem nebol vedený láskou k mladému telu, ale láskou $\mathrm{k}$ mládencovmu vnútru. Sókratés sa čuduje, že Alkibiadés sa chystá vystúpit' pred l'udovým zhromaždením a dávat' rady aténskym občanom. Kladie mu otázky ohl'adom predmetu týchto rád a o mládencovej kompetencii v otázkach vlády nad obcou. ${ }^{28}$ Ukazuje mu, že k politickej moci ho nepredurčuje ani majetok ani vznešený pôvod, ale iba schopnost' vládnut' sám nad sebou. Mat' v moci sám seba nie je nič iné ako starat' sa o seba. Sókratés Alkibiadovi vysvetl'uje, že práve teraz je preňho najlepší čas začat'. To, že sa skončila jeho výchova ako adolescenta, neznamená, že má zostat' v takom stave, v akom sa nachádza. Nebolo by správne konat' podl'a toho, čo sa mu momentálne zachce, ale vychovávat' samého seba, rozlišovat' dobré od zlého 
a nasledovat' to, čo je lepšie. V tomto bode začína mat' dialóg formu úsilia teoreticky zachytit', čo to znamená „starat' sa o seba“. Sókratés prepojí sloveso „starat' sa“ s príkazom napísaným na priečelí delfského chrámu boha Apollóna „poznaj sám seba“. Starat' sa o seba nie je myslitel’né bez sebapoznania. A toto sebapoznanie je podl'a Sókrata ovocím spoločného uvažovania - vedenia dialógu. V druhom kroku sa spoločne zamerajú na skúmanie, čo znamená toto „sám seba“ (auto to auto). Poukazom na to, že nemôže íst’ o „veci“, ktoré človek má, ani o „telo“, ale o to, čo „vládne“ telu aj veciam, čiže o „dušu“ (psyché). ${ }^{29}$ Poznanie vlastnej duše sa však tiež odohráva v spoločenstve. To najlepšie zo seba samého možno zachytit' iba v pohl'ade do zrkadla, ktorým je oko druhého, v pohl'ade do zrenice zrkadliacej vlastnú zrenicu. Ide teda o pohl'ad na to najlepšie v sebe samom prostredníctvom toho najlepšieho, čo je v druhom. To najlepšie $\mathrm{v}$ človeku, videnie a myslenie, je zároveň tým najbožskejším v človeku. Uvedomenie si týchto súvislostí je ovocím láskyplného pohl'adu. ${ }^{30}$

Sókratova reč v Alkibiadovi prebudí uvedomenie si vlastnej úbohosti a túžbu uniknút' z otrockého stavu k stavu slobody. Nazdáva sa, že vlastné sebazdokonal'ovanie závisí iba od Sókrata, ten ho však upozorní, že v diele starostlivosti o seba úspech nie je garantovaný automaticky. Podobne ako u Aischina, aj Platón (či ten, kto píše pod jeho menom) vyslovuje výhradu, že všetko v konečnom dôsledku závisí od nepredvídatel'ného činitel'a, ktorým je božia vôl'a: „Ak boh chce.“31 A čitatel'ovi, ktorý vie, ako sa skončí životný príbeh mladíka diskutujúceho so Sókratom, naznačí, že karty ešte môže zamiešat' ,silný vplyv štátneho života““, ${ }^{3}$ prít’ažlivost' inej lásky - lásky k moci a osobným ambíciám.

\footnotetext{
${ }^{1}$ Platón, Alkibiadés I 124c.

2 Platón, Obrana 30a-b.

${ }^{3}$ Porovnaj Platón, Lachés 187e-188a: „Zrejme nevieš, ako je to, ked’ niekto patrí k najbližším účastníkom rozhovorov so Sokratom a stýka sa s ním v diskusiách. Hoci sa najprv začne hovorit' o niečom celkom inom, nedá mu vol'nost' a zavádza reč koldokola, až je tak
} 
d’aleko, že sa sám pred ním spovedá, aký život teraz vedie a aký viedol v minulosti. Nuž a ked' je tak d'aleko, Sokrates ho nenechá odíst' prv, kým všetky tieto veci dokonale nepreskúma."

${ }^{4}$ Platón, Obrana 33c.

5 Platónov Sókratés však pred sudcami deklaruje svoju „nadstraníckost““ a uvádza príklad Chairefónta (priatel'a, ktorý si vyžiadal reakciu delfskej veštiarne ohl’adne Sókratovej múdrosti) ako prívrženca opozície voči oligarchickej vláde „Tridsiatich“ (Obrana 21a)

${ }^{6}$ Pasáž z Polykratovej Obžaloby sa nezachovala, no indíciu možno nájst’ v jednej $\mathrm{z}$ Isokratových rečí (Búsiris [= Reč 11] 5). Ako bolo spomenuté v poznámke $24 \mathrm{k} 3$. kapitole, Isokratés (na počudovanie) píše, že Polykratovo tvrdenie, že Sókratés bol Alkibiadovým učitel’om, sa nezakladá na pravde. Ak Isokratés naozaj o vzt'ahu medzi Sókratom a Alkibiadom nevedel, (neskoršia) spisovatel'ská aktivita sókratovských autorov tento vzt'ah naozaj potvrdzuje.

${ }^{7}$ Okrem vyššie spomenutej zmienky v reči Búsiris sa rečník Isokratés vyslovuje o Alkibiadovi s uznaním v reči $O$ štvorzáprahu ([=Reč XVI] 15-16) a hovorí, že Aténčania by mu mali byt' vd’ační. Naproti tomu rečník Lysias v dvoch rečiach Proti Alkibiadovi (Reč XIV 1 a Reč XV 1) ho vykresl'uje ako vierolomného muža, ktorý dokázal zradit' aj vlastných priatel'ov. Aténski rečníci tak upozorňujú na ambivalentnost' Alkibiadovej postavy, ktorá je tematizovaná aj v sókratovskej literatúre. K historickým súvislostiam porovnaj Rhodes 2011.

${ }^{8}$ Platón, Hostina 220e.

${ }^{9}$ Tamže 221a-c.

${ }^{10}$ Jeho reč pred zhromaždením je zaznamenaná u historika Thúkydida (Dejiny VI 16).

11 Tamže VIII 53, 3.

12 Diodóros Sicílsky, Historická knižnica XIV 11, 1-4.

${ }^{13}$ Cepko - Kalaš - Suvák 2020, 97-99.

${ }^{14}$ Diogenés Laertský, Životy II 64

${ }^{15}$ Tamže II 108. Žial', o obsahu Eukleidovho dialógu Alkibiadés sa nám z antiky nezachovali žiadne informácie. Poznáme iba jeho názov.

${ }^{16}$ Byzantský lexikón Súda, pod heslom „Faidón“. Zmienka o tom, že Faidón napísal dialóg Alkibiadés sa objavuje až v tomto neskorom zdroji z 10. storočia po Kristovi. Diogenés Laertský ho medzi Faidónovými spismi nespomína. Na druhej strane sa zmieňuje o tom, že práve Alkibiadés s Kritónom mali byt' tí, ktorých Sókratés poslal, aby vykúpili Faidóna z otroctva (Životy II 105).

${ }^{17}$ Diogenés Laertský, Životy VI 18. Súbor zlomkov týkajúcich sa tohto Antisthenovho spisu (V A 198-202 Giannantoni) možno nájst’ v Cepko - Kalaš - Suvák 2013, 471-480.

${ }^{18}$ Diogenés Laertský, Životy II 61. Súbor zlomkov z Aischinovho Alkibiada (VI A 41-54 Giannantoni) možno nájst' v Cepko - Kalaš - Suvák 2020, 94-136. 
${ }^{19}$ Platónovi sa pripisujú dva dialógy pod názvom Alkibiadés ( $I$ a II alebo Väčš a Menši). Možno ich nájst' v súbornom českom alebo slovenskom preklade Platónových spisov (Platón 2003 a Platon 1990).

20 Spomienky I 2, 12-47. Práve v tejto Xenofóntovej kapitole sa objavuje Alkibiadovo meno v paralele k vodcovi „Tridsiatich“ Kritiovi. Xenofón zdôrazňuje, že Alkibiadés sa nestal zápornou postavou vd’aka Sókratovej výchove, ale napriek nej.

21 Porovnaj zl. V A 198-199 Giannantoni.

${ }^{22}$ Porovnaj Alkibiadovu chváloreč na Sókrata v Platónovej Hostine (215b), kde ho prirovnáva k soške satyra, ktorá vo vnútri ukrýva zlatú podobizeň božstva. K Alkibiadovej reči v Platónovej Hostine porovnaj Jirsa 2007.

${ }^{23}$ Porovnaj zl. V A 200 a 202 Giannantoni.

24 Zl. VI A 46 Giannantoni.

25 Porovnaj zl. VI A 53 Giannantoni [= Aelius Aristides, $O$ rečníctve I 61 a 74]: „Keby som si myslel, že môžem byt' nejakým umením prospešný, sám by som sa obvinil z vel'kej nerozumnosti. Za týchto okolností som však nadobudol presvedčenie, že mi to bolo dané nejakým božím údelom. [...] Skutočne som nemal žiadne poznatky, ktoré by som mohol niekomu odovzdat' a takto byt' užitočný. Napriek tomu som bol presvedčený o tom, že iba jednoduchým stretávaním s ním by som ho mohol urobit' pôsobením lásky lepším.“ Aischinés pripisuje vychovávatel'skej láske dôležitú rolu aj v dialógu Aspasia, v ktorom Sókratés prezentuje ako „učitel'ku filozofie“ známu aténsku hetéru a Periklovu konkubínu (zl. VI A 59-72). O úlohe eróta v Aischinovej Aspasii porovnaj Ehlers 1966; v Aischinovom Alkibiadovi Kalaš - Zelinová 2019; Suvák - Cepko - Kalaš 2020; v Sókratovom výchovnom pôsobení vôbec Zelinová 2018, 136-157.

${ }^{26}$ K problému autenticity dialógu porovnaj Jirsa 2009. Corpus platonicum obsahuje aj kratší dialóg pod názvom Alkibiadés Menši (alebo Alkibiadés II), ktorý však kritici jednomysel'ne považujú za nepravý. Isteže, nepravost' dialógu by sama osebe nemusela byt' dôvod na to, aby sme ho v našom výbere ignorovali. Ked’že však jeho téma (o účinnosti modlitby) nesúvisí s témou, ktorej sa venujeme, a navyše, predpokladaný dátum jeho napísania (3. alebo 2. storočie pred Kristom) ho kladie mimo rámec sókratovskej literatúry, nebudeme mu na tomto mieste venovat' pozornost'.

27 Porovnaj Diogenés Laertský, Životy III 62; Albinos, Iamblichos, Olympiodóros.

${ }^{28}$ K politickému rozmeru (Pesudo-)Platónovho Alkibiada porovnaj Archie 2015; Helfer 2017.

29 Dejinám starostlivosti o seba venoval v roku 1982 cyklus prednášok pod názvom „Hermeneutika subjektu“ M. Foucault. Na viacerých miestach sa odvoláva na dialóg Alkibiadés Väčší. Podl'a neho je posun od „starostlivosti o seba“ k ,poznaniu seba“ Platónovou inováciou, a podobne aj interpretácia výrazu „sám seba“ v zmysle metafyzického substrátu, ktorým je „duša“ (Foucault 2005, 65-79). Porovnaj Suvák 2021, 147-152 a 201-207. 
${ }^{30}$ Podobný zbožštujúci pohl'ad Platón opisuje vo Faidrovi (250c-251c) a možno ho interpretovat' aj ako hybnú silu stúpania ku kráse samej po Diotiminom „rebríku lásky“ v Hostine (209e-212a).

${ }^{31}$ Alkibiadés I, $135 \mathrm{~d}$.

${ }^{32}$ Tamže $135 \mathrm{e}$. 


\section{Záver}

Sókratés prichádza s chápaním filozofie ako úsilia stat' sa po l’udskej stránke čo možno najlepším. Táto snaha o upevnenie vlastného charakteru a osobné zdokonal'ovanie je podl'a neho spätá s problémom poznania, ktoré je u človeka nevyhnutne limitované. Poznanie vlastných hraníc, teda poznanie seba samého, je prvým krokom na ceste autentickej l'udskej existencii. Dejiny antickej filozofie by sa dali interpretovat' ako hl'adanie návodu na plnohodnotný l'udský život - povedané Sókratovými slovami - ako „starostlivost' o seba“. Nejde však o egoistické uzatvorenie sa do seba, ale o úsilie, ktoré má aj svoj výchovný rozmer. Sókratovská starostlivost' o seba je zároveň apelom na druhých, aby prehodnotili vlastné presvedčenia a usilovali sa o to, čo je dobré, správne, spravodlivé nielen zdanlivo, ale ukáže sa takým aj po preverení prostredníctvom testu presvedčení vo filozofickom rozhovore.

Sókratovskí autori prvej polovice 4. storočia pred Kristom toto Sókratovo dedičstvo odovzdávajú d’alej, a to nie uniformným spôsobom, ale v pluralite foriem odrážajúcej osobnú skúsenost' každého z nich. Rôzne modely prelínania poznania a cnosti však nie sú charakteristické iba pre týchto niekol'ko dekád vo vývoji gréckeho myslenia, ked' ešte filozofia nepoznala rozlíšenie na svoje parciálne disciplíny, ale možno ich sledovat' 
aj d’alej - u Platóna, Aristotela, v helenistických školách a systémoch neskorej antiky. Chápanie filozofie ako nástroja sebatvorby však antikou nekončí. Vnímavý pozorovatel' dejín európskeho myslenia ho môže sledovat' ako nenápadný, no mocný spodný prúd, ktorý formuje aj našu súčasnost'. Nech pohl'ad na jeho počiatky, prezentovaný v tejto publikácii, inšpiruje aj dnes k obnove chápania filozofie ako návodu na autentický l'udský život. 


\section{Literatúra}

Archie, A. (2015): Politics in Socrates' Alcibiades. A Philosophical Account of Plato's Dialogue Alcibiades Major. New York: Springer.

Aristofanés (1996): Oblaky. Přel. J. Šprincl. Praha: Rezek.

Aristoteles (1979): Etika Nikomachova. Preložil J. Špaňár. Bratislava: Pravda.

Bleicken, J. (2002): Athénská demokracie. Přel. J. Souček. Praha: OIKOYMENH.

Brickhouse, T. C. - Smith, N. D. (2000): The Philosophy of Socrates. Boulder - Oxford: Westview Press.

Brickhouse, T. C. - Smith, N. D. (2004): Plato and the Trial of Socrates. New York - London: Routledge.

Bromberg, J. A. (2018): A Sage on the Stage: Socrates and Athenian Old Comedy. In: A. Stavru - Ch. Moore (eds.): Socrates and the Socratic Dialogue. Leiden - Boston: Brill, 31-63. 
Capra, A. (2017): Aristophanes' Iconic Socrates. In: A. Stavru - Ch. Moore (eds.): Socrates and the Socratic Dialogue. Leiden - Boston: Brill, 64-83.

Cepko, J. - Kalaš, A. - Suvák, V. (2016): Diogenis fragmenta. Diogenove zlomky. Bratislava: Univerzita Komenského v Bratislave.

Cepko, J. - Kalaš, A. - Suvák, V. (2020): Aeschinis Socratici fragmenta. Zlomky Aischina zo Sfétta. Bratislava: Univerzita Komenského $\mathrm{v}$ Bratislave.

Cepko, J. (2011): Antisthenés a paideia. K sókratovskému modelu výchovy. Filozofia, 66 (6), 535-544.

Cepko, J. (2019): Od konfliktu k zdatnosti. Aischinés a sokratovská výchova. Filozofia, 74 (1), 28-39.

Clay, D. (1994): The Origins of the Socratic Dialogue. In: P. A. Vander Waerdt (ed.): The Socratic Movement. Ithaca - London: Cornell University Press, 23-47.

Diogenes Laertios (1954): Životopisy slávnych filozofov. 2 zv. Preložil M. Okál. Bratislava: Vydavatel'stvo Slovenskej akadémie vied.

Dorion, L.-A. (2006): Xenophon's Socrates. Transl. S. Menn. In: S. Ahbel-Rappe - R. Kamtekar (eds.): A Companion to Socrates. Oxford: Blackwell Publishing, 93-109.

Ehlers, B. (1966): Eine vorplatonische Deutung des sokratischen Eros. Der Dialog Aspasia des Sokratikers Aischines. München: Verlag C. H. Beck.

Filonik, J. (2013): Athenian Impiety Trials: A Reappraisal. Dike - Rivista di storia del diritto greco ed ellenistico, 16, 11-96.

Flachbartová, L. (2015): Diogenovský kynizmus ako spôsob života. Prešov: Filozofická fakulta Prešovskej univerzity.

Foucault, M. (2005): The Hermeneutics of the subject. Lectures at the Collège de France, 1981-1982. Transl. G. Burchell. New York: Palgrave Macmillan.

Giannantoni, G. (1990): Socratis et Socraticorum reliquiae. 4. zv. Napoli: Bibliopolis. 
Graeser, A. (2000): Řecká filosofie klasického období. Přel. M. Petříček. Praha: OIKOYMENH.

Guthrie, W. K. C. (1971a): The History of Greek Philosophy. Vol. III, The Fifth-Century Enlightenment - Part 1: The Sophists. Cambridge: The Cambridge University Press.

Guthrie, W. K. C. (1971b): The History of Greek Philosophy. Vol. III, The Fifth-Century Enlightenment - Part 2: Socrates. Cambridge: The Cambridge University Press.

Guthrie. W. K. C. (1975): The History of Greek Philosophy. Vol IV, Plato, the Man and His Dialogues: Earlier Period. London - New York Melbourne: Cambridge University Press.

Havelock, E. A. (1963): A Preface to Plato. Cambridge, MA - London: Belknap Press.

Helfer, A. (2017): Socrates and Alcibiades. Plato's Drama of Political Ambition and Philosophy. Philadelphia: University of Pennsylvania Press.

Homéros (1986a): Ílias. Preklad M. Okál. Bratislava: Slovenský spisovatel'.

Homéros (1986b): Odysseia. Preklad M. Okál. Bratislava: Slovenský spisovatel'.

Hornblower, S. - Spawforth, A. - Eidinow, E. (eds.): The Oxford Classical Dictionary. 4. vyd. Oxford: Oxford University Press.

Jaeger, W. (1946): Paideia: the Ideals of Greek Culture. Vol. I: Archaic Greece. The Mind of Athens. Transl. G. Highet. Oxford: Blackwell. Jaeger, W. (1947): Paideia: the Ideals of Greek Culture. Vol. II: In Search of the Divine Centre. Transl. G. Highet. Oxford: Blackwell.

Jaeger, W. (1986): Paideia: the Ideals of Greek Culture. Vol. III: The Conflict of Cultural Ideals in the Age of Plato. Transl. G. Highet. New York - Oxford: Oxford University Press.

Jirsa, J. (2007): Alcibiades' Speech in the Symposium and Its Origins. In: A. Havlíček - F. Karfík (eds.): Plato's Symposium. Praha: OIKOYMENH, 279-292. 
Jirsa, J. (2009): Authenticity of the Alcibiades I: Some Reflections. Listy filologické, 82 (3-4), 225-244.

Kahn, Ch. H. (1996): Plato and the Socratic Dialogue. The Philosophical Use of a Literary Form. Cambridge: Cambridge University Press.

Kalaš, A. - Suvák, V. (2010): Antisthenés. Bratislava: Kalligram.

Kalaš, A. - Suvák, V. (2013): Antisthenis fragmenta. Antisthenove zlomky. Bratislava: Univerzita Komenského v Bratislave.

Kalaš, A. - Zelinová, Z. (2019): Alkibiadov pedagogický eros? Filozofia, 74 (1), 13-27.

Konrádová, V. (2016): Sókratés a achilleovské paradigma. In: J. Jinek (ed.): Platónova Obrana Sókrata. Praha: OIKOYMENH, 102-117. Montuori, M. (1998): Socrate. Fisiologia di un mito. 3. vyd. Milano: Vita e pensiero.

Moore, Ch. (2017): Xenophon's Socratic Education in Memorabilia Book 4. In: A. Stavru - Ch. Moore (eds.): Socrates and the Socratic Dialogue. Leiden - Boston: Brill, 500-520.

Nails, D. (2002): The People of Plato. A Prosopography of Plato and Other Socratics. Indianapolis - Cambridge: Hacket Publishing Company.

Platon (1990): Dialógy. 3 zv. Preklad J. Špaňár. Bratislava: Tatran.

Platón (2003): Platónovy spisy. 5 zv. Preklad F. Novotný. Praha: OIKOYMENH.

Porubjak, M. (2006): Xenofón a jeho obraz Sokrata. In: Xenofón: Hostina.

Sokratova obhajoba. Prel. A. Kalaš. Bratislava: Kalligram, 11-29.

Porubjak, M. (2010): Vôl'a (k) celku. Človek a spoločenstvo rečou Homéra a Theognida. Pusté Úl'any: Schola philosophica.

Porubjak, M. (2012): Sókratés a problém interpretácie dejín filozofie. Filozofia, 61 (1), 83-88.

Porubjak, M. (2019): Praktická protofilozofia Tyrtaia a Theognida. Trnava: Univerzita sv. Cyrila a Metoda.

Prior, W. J. (1991): Virtue and Knowledge. An Introduction to Ancient Greek Ethics. London - New York: Routledge. 


\section{Literatúra}

Rankin, H. D. (2014): Sophists, Socratics and Cynics. Abingdon: Routledge.

Redfield, J. M. (2017): The Origins of the Socratic Dialogue: Plato, Xenophon, and the Others. In: A. Stavru - Ch. Moore (eds.): Socrates and the Socratic Dialogue. Leiden - Boston: Brill, 125138.

Rhodes, P. J. (2011): Alcibiades. Barnsley: Penn \& Sword Military.

Rossetti, L. (1977): Aspetti della letteratura socratica antica. Chieti: Libera Università degli Studi G. D’Annunzio, Facoltà di lettere e di filosofia.

Rossetti, L. (1980): Ricerche sui dialoghi socratici di Fedone e Euclide. Hermes, 108, 183-200.

Rossetti, L. (2017): Philosopher Socrates? Philosophy at the Time of Socrates and the Reformed Philosophia of Plato. In: A. Stavru - Ch. Moore (eds.): Socrates and the Socratic Dialogue. Leiden - Boston: Brill, 268-298.

Rowe, Ch. (2006): Socrates in Plato's Dialogues. In: S. Ahbel-Rappe - R. Kamtekar (eds.): A Companion to Socrates. Oxford: Blackwell Publishing, 159-170.

Sellars, J. (2003): Simon the Shoemaker and the Problem of Socrates. Classical Philology, 98, 207-216.

Smith, N. D. (2018): A Problem in Plato's Hagiography of Socrates. Athens Journal of Humanities and Arts, 5 (1), 81-103.

Stavru, A. - Moore, Ch. (eds.) (2017): Socrates and the Socratic Dialogue. Leiden - Boston: Brill.

Suvák, V. - Cepko, J. - Kalaš, A. (2020): The Socratic Concept of the Care of the Self Based on the Analysis of Aeschines' Alcibiades (fr. SSR VI A 50). Ostium, 16 (1).

Suvák, V. (2008): Antisthenés: výklad Homéra. Filozofia, 63 (1), 50-62.

Suvák, V. (2011): Antisthenés medzi Sókratom a Diogenom. Filozofia, 66 (6), 545-557.

Suvák, V. (2013): O dialektickom charaktere Antisthenovho Aianta a Odyssea. Filosofický časopis, 61 (1), 33-50. 


\section{Literatúra}

Suvák, V. (2017a): Antisthenés. Štyri štúdie. Prešov: Vydavatel’stvo Prešovskej univerzity.

Suvák, V. (2017b): Sókratés a sokratika I. 2. vyd. Prešov: Prešovská univerzita.

Suvák, V. (2019): Aischinés zo Sféttu: sokratovec alebo podvodník, autor alebo plagiátor. Filozofia, 74 (1), 1-12.

Suvák, V. (2020): Ars vivendi alebo Umenie žit medzi Sókratom a Foucaultom. Bratislava: Vydavatel'stvo Spolku slovenských spisovatel'ov.

Suvák, V. (2021): Foucault. Od starosti o seba k estetike existencie a ešte d'alej. Bratislava: Petrus.

Škvrnda, F. (2020): Sokratovská otázka ako problém historiografie antickej filozofie. Bratislava: Univerzita Komenského.

Vander Waerdt, P. A. (1994): Socrates in the Clouds. In: P. A. Vander Waerdt (ed.): The Socratic Movement. Ithaca - London: Cornell University Press, 48-86.

Vander Waerdt, P. A. (ed.) (1994): The Socratic Movement. Ithaca London: Cornell University Press.

Vlastos, G. (1971): Introduction: The Paradox of Socrates. In: G. Vlastos (ed.): The Philosophy of Socrates. A Collection of Critical Essays. Garden City, NY: Anchor Books, 1-21.

Vlastos, G. (1991): Socrates, Ironist and Moral Philosopher. Ithaca - New York: Cornell University Press.

Wollner, U. (2017): Achilles - Sókratov vzor? (Apol. 28b3-d6). Filozofia, 72 (2), 103-113.

Xenofón (1972): Vzpomínky na Sókrata. Preklad V. Bahník. Praha: Svoboda.

Xenofón (2006): Hostina. Sokratova obhajoba. Prel. A. Kalaš. Bratislava: Kalligram.

Zelinová, Z. (2018): Paideia v sokratovskej filozofii. Bratislava: Univerzita Komenského v Bratislave.

Zelinová, Z. - Kalaš, A. (2021): Fysiognómonika - zabudnuté antické umenie. Bratislava: Univerzita Komenského v Bratislave. 


\section{Literatúra}

Zeller, E. (1843): Die Philosophie der Griechen. Zweiter Theil: Sokrates, Plato, Aristoteles. Tübingen: Verlag Ludwig Friedrich Fues. 
Jaroslav Cepko

POZNANIE A CNOSŤ

V SÓKRATOVSKEJ LITERATÚRE

Vydalo Belianum, vydavatel'stvo Univerzity Mateja Bela

v Banskej Bystrici v roku 2021.

Rozsah 70 strán; 3,63 AH. Prvé vydanie.

Publikované online.

ISBN 978-80-557-1922-1

https://doi.org/10.24040/2021.9788055719221 